Board of Governors of the Federal Reserve System

\author{
International Finance Discussion Papers
}

Number 908

November 2007

External Governance and Debt Agency Costs of Family Firms

Andrew Ellul, Levent Guntay, and Ugur Lel

NOTE: International Finance Discussion Papers are preliminary materials circulated to stimulate discussion and critical comment. References to International Finance Discussion Papers (other than an acknowledgment that the writer has had access to unpublished material) should be cleared with the author or authors. Recent IFDPs are available on the Web at www.federalreserve.gov/pubs/ifdp/. 


\title{
External Governance and Debt Agency Costs of Family Firms ${ }^{*}$
}

\author{
Andrew Ellul, Levent Guntay, and Ugur Lel ${ }^{* *}$
}

\begin{abstract}
We investigate the impact of family blockholders on the firm's debt agency costs under different investor protection environments. On one hand, families - through their undiversified investments, inter-generation presence, and reputation concerns - can mitigate debt agency costs. On the other hand, families - through their unique power position that can lead to private benefits extraction and higher bankruptcy risk - can exacerbate debt agency costs. The actual impact can go either way and what matters should be the creditors' protection environment. Using international bond issues from 1995 to 2000 for 1,072 international firms originating from 24 different countries, we find that family firms originating from low investor protection environments suffer from higher debt costs compared to non-family firms, while family firms originating from high investor protection environments benefit from lower debt costs compared to non-family firms. We find no impact from non-family blockholdings. These results are robust to various specifications and confirmed by an out-of-sample test using bonds issued by U.S. and foreign firms listed in the U.S. originating from 27 different countries.
\end{abstract}

Keywords: Ownership Structure; Family Firms; Agency Costs; Corporate Governance

JEL Classifications: G30, G32, F30

*Acknowledgements: We are grateful to Utpal Bhattacharya, Bruno Biais, Arnoud Boot, Mike Burkhart, Thomas Chemmanur, Stijn Claessens, Zsuzsanna Fluck, Joe Gagnon, Mariassunta Giannetti, Ronen Israel, Tullio Jappelli, Karl Lins, Michael Lemmon, Sreenivas Kamma, Massimo Massa, Colin Mayer, Darius Miller, Giovanna Nicodano, Eric Nowak, Mario Padula, Marco Pagano, Avri Ravid, David Reeb, Per Stromberg, David Thesmar, David Webb and participants during the Western Finance Association Annual Meeting (2007), European Corporate Governance Network Conference (Istanbul, May 2004), the Conference on Governance of Closely Held Firms (Copenhagen, June 2005), the JFI Conference on "The Ownership of the Modern Corporation" (Amsterdam, September 2005), the Asia-Pacific Corporate Governance Conference (Hong Kong, August 2005), the Summer Research Conference at the Indian School of Business (August 2006), and seminars at Hebrew University of Jerusalem, IDC Herzliya, Indiana University, INSEAD, London School of Economics, Pompeu Fabra, Tel Aviv University, Universita' di Napoli Federico II, University of Lugano, and University of Vienna for useful comments. The opinions expressed in this paper are not necessarily those of the Board of Governors, other members of its staff, or the Federal Reserve System.

${ }^{* *}$ A. Ellul and L. Guntay: 1309 E. Tenth St., Bloomington, IN 47405-1701, anellul@indiana.edu and 1guntay@indiana.edu. U. Lel: Division of International Finance, Federal Reserve Board, Washington, DC 20551,(202)452-3168,ugur.lel@frb.gov. 


\section{Introduction}

How does the presence of a large shareholder in a firm's ownership structure affect bondholders? And how does country-level governance influence this relationship? Theoretical literature has so far focused on the agency conflict between a blockholder and minority shareholders. Following Shleifer and Vishny (1997), we know that when "large owners gain nearly full control of the corporation, they prefer to generate private benefits of control that are not shared by minority shareholders". We also know that blockholders can abuse their dominant position especially when weak legal protection exists (Bebchuk, 1994, Stiglitz, 1985). Differential voting or pyramids are two mechanisms that can be used to facilitate expropriation. ${ }^{1}$ Can we extend the same Shleifer-Vishny (1997) argument to analyze how large blockholders' preference for such private benefits may have an impact on bondholders as well? Can the extraction of private benefits damage bondholders as well? And, if yes, how significant are these debt agency costs?

Family-owned firms are very similar in spirit to the firm modeled by Shleifer and Vishny (1986). Equally important, recent U.S. and international evidence on ownership of publicly traded firms highlights the presence and importance of firms where the founding family has a significant stake. Only about $36 \%$ of international large public traded firms are widely held, while $45 \%$ are owned by families (La Porta et al., 1999) ${ }^{2}$. Family firms' presence in the U.S. is also significant with almost one third of S\&P500 firms and 37\% of Fortune 500 considered as family-owned (Anderson and Reeb, 2003, and Villalonga and Amit, 2006).

In this paper, we investigate how blockholders - specifically family blockholders - behave with bondholders when they find themselves in a power position and ask two main questions. First, does a founding family exacerbate or mitigate the agency cost of debt? Second, does this behavior change in the presence of different investors' protection regimes? We investigate the impact of the founding family on the debt agency costs by looking at bond issues made by a) 1,072 international firms from 24 countries over the period 1995-2000 and b) 328 U.S. and firms with Level II or III ADRs from 27 countries. We find that the impact of the family blockholder on bondholders is heavily influenced by the level of country-level governance and that debt finance providers act rationally

\footnotetext{
${ }^{1}$ See Grossman and Hart, 1988, Harris and Raviv, 1990, La Porta et al., 1998.

${ }^{2}$ See also Claessens et al. (2000), Faccio and Lang (2002).
} 
and price bonds accordingly. Interestingly, we find no such impact produced by institutional blockholders implying a significant behavior difference between different types of blockholders.

Why do we focus on family blockholders? As we explain below, we expect that bondholder-blockholder conflicts are clearest in the case of a family blockholder rather than, say, an institutional blockholder. We consider two broad explanations for differences between family and institutional blockholders. First, the blockholder's riskreduction behavior that comes from the level of portfolio diversification. Second, the long term presence/commitment to the firm that different types of blockholders show. Third, the blockholder's propensity and ability to extract wealth from the firm that can endanger the bondholders' position.

We argue that unlike widely-held financial institutions, a founding family (a) has a highly undiversified investment in the firm, leaving it open to significant idiosyncratic risk, (b) has a long-term commitment to the firm, often spanning different generations, and (c) faces a situation where its reputation (and, in some cases, its national and international prestige) is strictly related to the firm's performance. These characteristics cannot be easily replicated by institutional investors which are likely to have diversified investments, and their involvement with the firm is more of a short-term nature. For example, Tufano (1996) shows that institutional investors often have significant shareholdings in different companies, are not active in monitoring management and are more likely to have incentive structures similar to atomistic shareholders. Wahal (1996) and Gillian and Starks (2000) find that institutional blockholders are ineffective as monitors. In general, Karpoff (2001) reports that institutional shareholder activism can, at best, lead to small changes in firms' governance and no significant impact on firms' earnings and performance.

Secondly, if it is argued that the driving force behind the debt agency conflict is the blockholder's ability to extract private benefits, a channel that increases bankruptcy risk $^{3}$, then we have to address a second question: do different types of blockholders have

\footnotetext{
${ }^{3}$ The case of Parmalat SpA is a clear example on how a family's extraction of private benefits can lead to a firm's bankruptcy. There are also other activities undertaken by a family that can increase the risk of bankruptcy, without necessarily leading to actual bankruptcy, and that leads to a deterioration of the firm's credit ratings. One such example is the recent case of the Dolan family in their dealings with Cablevision. The Financial Times (27 October 2005) had this to say on this case: "Bondholders were relieved to see the
} 
the same incentives and abilities to extract private benefits from small shareholders and bondholders? The answer is probably not. Often, founding families are in a very uncommon power position in the firm obtained through either their massive presence in the firm's management or through the use of very complex ownership structures. In such cases, the family may use ownership pyramids and cross-shareholdings so that their control rights end up being significantly higher than their cash flow rights. More importantly, the dilution of any private benefits extracted differs between family and nonfamily blockholders. In the case of widely-held financial institutions, any private benefits extracted are likely to be divided among several final owners, resulting in heavy dilution of such benefits. On the contrary, dilution is not a problem for a family.

Having established that concentrated ownership - particularly a family blockholder - may exacerbate debt agency costs, we need to ask an additional question: can the external (country-level) governance environment influence the bondholderblockholder relationship? Specifically for our research, we ask how families are disciplined and monitored in order to avoid private benefits consumption and understand how finance-providers protect themselves from such behavior. Existing evidence shows that the ultimate impact of a large shareholder is likely to depend on both the type of internal and external governance. For example, Claessens et al. (2002), interpreting the results found on the impact of large blockholders on firm valuation in East Asian countries, state that "the degree to which certain ownership and control structures are associated with entrenchment discounts likely depends on economy-specific circumstances." Lins (2003) finds that the way blockholders impact firm valuation is significantly influenced by the type of shareholder protection rules in each country. Lins state that "one interpretation of these results is that external shareholder protection mechanisms play a role in restraining managerial agency costs...”

The only previous empirical evidence on the relationship between family firms and debt agency costs is provided by Anderson et al. (2003) who use S\&P 500 firms and find that family firms pay less (32 basis points) in debt costs compared to non-family firms. Their results are consistent with the long-term nature of founding family's

back of potentially massive additional leverage and the associated threat of multiple credit rating downgrades for the cable operator...The Dolan's methods may be unorthodox but bondholder anxiety about "shareholder-friendly" activities...is not limited to Cablevision." 
investment that aligns the interests of family blockholders and bondholders. Such longterm presence creates a structure that appears to be providing insurance to bondholders and protecting their interests.

The results for family firms in the U.S. labor under one important constraint, namely that they are obtained for firms operating in a particular type of market environment characterized by transparency and a well-regulated financial system with high financial discipline. That is not the typical environment encountered internationally. Hence we argue, similar to La Porta et al. (1999), that we need to address another significant question: What happens to debt agency costs in systems where, because of lack of proper financial discipline and weak legal protection, large shareholders can expropriate bondholders more easily?

We find that family ownership matters for debt agency costs and such an impact changes across the different investors' protection regimes. In particular, we find that family firms originating from countries with low creditors' protection face higher costs of debt relative to non-family firms. We find that while in high creditors' protection environments family-owned firms pay 23 basis points less than non-family firms, in low protection environments family-owned firms pay 35 basis points more than non-family firms. ${ }^{4}$ This result, while being both statistically and economically significant, is robust to various specification and inclusion of various firm-level, bond-level and country-level variables. Our results confirm that the country-level monitoring mechanism influences the behavior of blockholders and that finance-providers change their behavior - and the premium they ask for - accordingly.

While this sample of international firms provides us with significant benefits, it also presents us with a number of limitations that should be fully addressed. First, it is reasonable to expect that debt agency costs are a function of both internal (firm-level) and external (country-level) governance. The firms we use have varying degrees of internal governance and this may influence our results. Second, there are well-known crosscountry differences that can generate problems, particularly a spurious relationship between external financing and investors' protection (Rajan and Zingales, 1998). Obviously, any international comparison will labor under significant problems such as

\footnotetext{
${ }^{4}$ The exact impacts differ across different econometric specifications and the use of different indices that measure investor protection.
} 
different disclosure regimes, different accounting standards and different investment cultures that are likely to impact the cost of debt.

To solve these problems, we do an out-of-sample test using Level II or Level III ADR firms from 27 countries and U.S. firms in the Fortune 500 list in the period from 1988 to 2002. This dataset in this test comprises 328 firms originating from different creditors' protection systems, giving us a whole spectrum in terms of legal protection and financial transparency but with similar internal governance. This sample is important since our research question is focused on external (country-level) governance rather than internal governance. Existing literature has established the advantages of cross-listing in the U.S. derived from the "bonding" hypotheses: international firms that have already decided to list on the American market should have better corporate governance and better disclosure standards compared to other firms that remain exclusively listed on their local market (Coffee, 2002, La Porta et al., 2000, Miller and Puthenpurackal, 2002, and Stultz, 1999). This argument can be mostly applied to Level II and Level III ADRs but not to Level I ADRs. The latter have no obligation to adhere with the highest standards required by the New York Stock Exchange. Using Level II and Level III ADRs allows us to be confident that any result we find is driven by external, not internal, governance. The second advantage is that ADRs allow us to minimize cross-country differences. ${ }^{5}$ The results of such out-of-sample test confirm the monitoring hypothesis because they confirm the results obtained for the sample of non-ADR firms. As expected, the economic impact of the blockholder's presence for the ADR sample is smaller relative to the non-ADR sample.

These results show that "who monitors the family" (La Porta et al., 1999, page 502 ) is a crucial issue and that founding families' can exacerbate or mitigate the agency cost of debt depending on the investor protection environment under which they operate in their home country.

We also show that there are significant differences between founding families and other types of large blockholders, such as institutional blockholders. In particular, we find

\footnotetext{
${ }^{5}$ Several papers suggest cross-listing improves foreign firms' governance environment, i.e., the 'bonding hypothesis'. If that is true for our sample of cross-listed firms, the bias should work against our ability to find statistically significant relation between country level governance mechanisms and family-related debt costs.
} 
no relationship between other types of large blockholders, such as institutional blockholders, and debt agency costs. Debt costs are also insensitive to whether an institutional investor has a presence in active management. This confirms our view that family blockholdings are different than non-family blockholdings.

We contribute to the literature in various ways. First, we contribute to the emerging literature that investigates the link between ownership structures and debt agency costs rather than the traditional manager-shareholder agency costs. Up to now, only Barnea et al. (1981), Bagnani et al. (1994) and Anderson et al. (2003), have explicitly considered this area of research. Second, we provide one possible answer to the question of who bears these debt agency costs in different legal environments. Third, we contribute to the literature that investigates the impact of ownership structures on firm's valuation. While Lins (2003) finds in favor of a presence of a large blockholder, especially in the presence of management's control rights, we find a more complex story where a large blockholder is considered as a positive development in high investors' protection environments but judged as negative in low investors' protection regimes. Fourth, we contribute to the literature on the behavior of blockholders, showing that blockholders cannot be treated as a single block: different economic incentives of different blockholders produce different types of behavior and impacts.

The rest of the paper is organized as follows. Section 2 presents the hypotheses to be tested. Section 3 reviews the data and the methodology we use. Section 4 presents and reviews the results. Section 5 concludes.

\section{Section 2. Hypotheses}

Existing theoretical literature does not provide significant prior indications about the family's behavior vis-à-vis bondholders. Nevertheless, we can look at indications offered by existing theoretical literature on blockholders' behavior, and some very recent empirical literature on family firms to devise hypotheses.

Shareholders can engage into two types of behavior to expropriate bondholders. They can either engage in asset substitution as observed by Jensen and Meckling (1976) or engage in stealing or tunneling of the firm's resources. From an empirical point of view, the crucial issues are the magnitude and the likely impact of these agency costs. 
What matters most to bondholders is not where agency costs are coming from, but whether the blockholder's behavior could cause the firm to get closer, or into, bankruptcy. $^{6}$ A family blockholder can engage in both asset substitution and stealing/tunneling at the same time.

Given the blockholders' incentives, bondholders would want to protect themselves through higher rents, resulting in higher cost of debt capital. The question then is whether a large, undiversified blockholder, such as a founding family, has any incentive to expropriate bondholders, or whether its incentives are better aligned with those of bondholders.

Empirical literature on family firms has identified various aspects of having a family in the ownership structure. First, founding families often have highly undiversified investment and thus may be affected adversely by the firm's idiosyncratic risk (Maug, 1998), something that should keep a family firm from taking excessive risks. Second, families tend to have very long horizons for their investments, and are the classical type of long-term investors, unlike other types of (institutional) blockholders. Their long-term presence in the firm, which often spans different generations, allows the building of strong relationships between the firm and the financial markets. Third, families want to pass the firm to subsequent generations. This means that they value highly the survival of the firm, perhaps much more than the simple wealth maximization required from other firms. Once survival becomes a priority, taking on excessive risk should not be one of the founding family's objectives. If one also adds the fact that the family's reputation is very much linked with the firm's reputation and success then it is not unreasonable to argue that the family's incentives could be very much aligned with those of bondholders who prefer to reduce risk, and hence lower possibilities of expropriation of bondholders. We can view these factors as the "sunny side" of the family blockholding?

\footnotetext{
${ }^{6}$ It is also probably true, however, that risk shifting, by virtue of the negative effects generated on bondholders through the changing of the whole distribution of cash flows available to the different stakeholders (the well-documented mean preserving spread), may get the firm closer to bankruptcy more so than stealing or tunneling that have the sole impact of shifting the mean rather than the entire distribution of cash flows.

${ }^{7}$ One may also add that a large blockholder, not having a position in the firm's management, may monitor the manager closely so as not to allow a poorly devised strategy, such as takeovers or diversification, to develop into poor performance that may end up in some kind of restructuring that will hurt bondholders (Gibbs, 1993, Hoskisson et al., 1994).
} 
On the other hand, there is also what may be called the family's "dark side" which, through its power position, could use various mechanisms and opaqueness in the firm's organization to expropriate cash flows from the firm and direct them into its own pockets or use them for "pet projects". This behavior should lead to an increase in debt agency costs. The classical example is Parmalat SpA where the family controlling this publicly-owned firm consistently diverted cash raised by Parmalat SpA to its other businesses and "pet projects"8 leading to the firm's eventual bankruptcy. Backman (1999), investigating Asian corporate groups, documents how controlling families used cross-holdings and pyramids to expropriate stakeholders.

It is not unreasonable to argue that the actual behavior of the founding family can go either way. It can be an excellent mechanism that, through the focus on firm's survival, trust and long-term relationships generated across generations, aligns the incentives of the large shareholder with those of bondholders. On the other hand, through its power position, it can actually have higher incentives and be in a position to expropriate bondholders.

These alternative modes of behavior raise various questions on the way a founding family is disciplined and monitored. Existing literature on corporate governance suggests that the legal environment and the financial market's structure should have an impact on agency conflicts (see Claessens et al., 2000, Durnev and Kim, 2005, Lins, 2003, Stulz, 2005, Weinstein and Yafeh, 1998, amongst many others). We argue that the role of a family in mitigating or exacerbating debt agency costs depends on how market discipline is exercised. This will determine how much power a family can exert within the firm and to what extent is the family itself is monitored by the financial market.

Where capital market institutions are effective in their disciplinary role and minority shareholders' and bondholders' protection rules are in place and effective, one expects that having a family within the firm's ownership structure leads to a mitigation of debt agency costs. This is mainly due to the long-term, and undiversified, nature of family investments which allow the building of strong relationships between the firm and the bond markets. Well-functioning capital markets should control the "dark side" of the family, allowing the firm to enjoy lower cost of financing.

\footnotetext{
${ }^{8}$ The Tanzi family used part of the cash flows for its own travel company and its soccer club.
} 
But what happens when capital market institutions are not effective and bondholders' protection rules are not enforced? In this case, it is reasonable to expect that it is easier for concentrated ownership to expropriate bondholders (and minority shareholders). In this case, there may be nothing controlling the "dark side" of the family impact and its presence may end up increasing debt agency costs. Expecting this situation, bondholders will ask a higher return for bonds issued by family firms to be compensated for the risk of expropriation.

After having established the impact of country-level governance, we have to address other questions related to this issue. First, what is so special about founding families? Can another type of blockholder engage in similar behavior? And what differentiates a founding family from, say, a powerful CEO of a firm with dispersed shareholders? We first address the former case and then the latter. Financial institutions, which are the other type of blockholders typically found in firms around the world, are not usually long-term investors and as such can built very limited, if any, relationships between the firm they invest in and the financial markets. Moreover, the incentives of such blockholders to extract private benefits is, most probably, low because these private benefits have to then be divided among several final owners, resulting in heavy dilution of such benefits. Dilution is not likely to be a problem for a founding family.

The case of a powerful CEO of a firm with dispersed owners is slightly different. It is true that dilution of such private benefits is not a problem for such a manager and hence she may have similar incentives. The question then is whether a manager has the abilities to engage in systematic stealing/tunneling or risk shifting behavior for a very long time. To achieve such a goal, one would need to set-up a very opaque organizational structure and collude, systematically, with different layers of management. Such schemes involve significant costs, one example being legal maneuvering. We posit that it is very unlikely that such circumstances can occur, at least for a long period, in a widely held firm with a powerful manager. On the other hand, by virtue of its power position and its ability to stay in the firm's management for a long time, a founding family can more easily reach such an objective. Perhaps the parallel examples of Enron and Parmalat can be helpful to illustrate the point. Although Enron had a powerful CEO managing a widely held corporation, the web of structures and off-balance sheet trusts were reported in financial statements. On the other hand, the web of offshore companies created by 
Parmalat were never reported in financial statements and the organizational structure was so obscure that until now, almost five years after its bankruptcy, prosecutors have not fully identified the exact operations in different entities.

There is, though, another important issue to consider when addressing different behavior in different legal environments. What if a firm's ownership structure is an equilibrium response to the legal environments in which a firm operates, or the particular operational characteristics of the firm (Demsetz and Lehn, 1985, Roe, 1990, and Demsetz and Villalonga, 2001)? There are some studies that show that the ownership stake of a controlling blockholder may mitigate, but not eliminate completely, the incentive of expropriating minority shareholders (Filatotchev et al., 2001, La Porta et al., 1999). In this case, one can argue that the institution of the family shareholding - by virtue of its long-term commitment to the firm - is an important mechanism through which trust can be built between the firm and financial markets.

While the trust argument should apply to family firms in both high and low financial discipline environments, it can be more important in the latter. Such environments are characterized by significant incomplete contracts situations where there are no proper mechanisms in place to resolve some of the most important and acute conflicts that may arise between different stakeholders. Building trust can be one of the most effective mechanisms to resolve these conflicts. Using this argument, family firms should always enjoy lower cost of debt, whether they come from low or high financial discipline environments. One can even say that marginal benefit should be greater for firms operating in the former.

This discussion leaves us with two competing hypotheses about the relationship between family blockholding and bondholders. The first one states that, if external governance matters, then founding families operating in high financial discipline environments will mitigate debt agency costs but should exacerbate these costs in low financial discipline environments. Hence, we would expect debt costs to be lower (higher) for family firms (compared to non-family firms) in high financial discipline environments (low financial discipline environments). 
On the other hand, if external governance mechanisms do not matter, then family firms - through their ability to build long-term relationships with bondholders - should mitigate the agency costs of debt in both high and low financial discipline environments.

\section{Section 3. Data}

We use two different samples of firms to investigate our hypotheses. The first sample - henceforth "Sample A" - consists of 1,072 international firms, while the second - henceforth "Sample B" - consists of 328 international firms. We build Sample A from three different sources. First, we use the dataset of Claessens et al. (2000) ${ }^{9}$ that provides ownership information for 2,980 publicly traded corporations from nine East Asian countries (Hong Kong, Indonesia, Japan, South Korea, Malaysia, the Philippines, Singapore, Taiwan, and Thailand). Ultimate ownership data is collected for all owners that hold more than 5\% of a company's stock for the period 1996 and 1998. Second, we use the dataset of Faccio and Lang $(2001)^{10}$ that reports ultimate ownership for 5,232 corporations in 13 Western European countries (Austria, Belgium, Finland, France, Germany, Ireland, Italy, Norway, Portugal, Spain, Sweden, Switzerland and United Kingdom) over the period 1996 to 1999. Ultimate ownership data is collected for all owners that hold at least $10 \%$ of a company's stock. Third, we also add U.S. firms in the Fortune 500 list as of 1995 for which we manually collect ultimate ownership information.

Next, we use the New Issues Database of the Securities Data Company (SDC) to identify the firms for which we have ownership information and that have issued bonds. We find that out of a total sample of 8,712 international firms, 1,353 firms have issued 10,568 non-convertible corporate bonds and notes between January 1995 and December 2000. From this sample, we then delete observations for which the Yield-to-Maturity is not reported in the SDC database. Additionally, we restrict our sample to bond issues for which we can find at least the 3-month Government (Treasury) rate in the currency of the bond issue. After these deletions, we end up with 1,072 firms and 8,835 bond issues. We also collect information about the bond ratings by Moody's or S\&P but we are able to

\footnotetext{
${ }^{9}$ The dataset is available at http://jfe.rochester.edu/data.htm.

${ }^{10}$ The dataset is available at http://jfe.rochester.edu/data.htm
} 
only get such information for 6,015 bonds issued by 659 firms. We will use this subsample to check the robustness of results to the inclusion of bond ratings.

Sample B - which we will use for the out-of-sample test - is made up of all U.S. firms in the Fortune 500 list as of 1988 and Level II or III ADRs listed on the NYSE in the period 1988 - 2002. We identify 743 firms (331 U.S. firms and 412 Level II and III ADRs) that are in the Compustat Industrial tapes and we collect information about their ownership structure through either the $20-\mathrm{F}$ forms or proxy statements. From the latter we collect two different sets of information. First, we get information about the presence of a founding family, either directly or indirectly through a separate entity (such as a trust) owned by the founding family. Second, in the case of a family presence, we collect data on the family's ultimate ownership stake. We also obtain data on whether a family is present in the firm's management in a similar way, i.e. from 20-F forms and proxy statements we determine whether members of a family are present on the firm's Board of Directors. From the same sources we also obtain information about the presence and ownership stake of non-family blockholders and whether they are inside blockholders (where they have a presence on the firm's Board of Directors) or outside blockholders (where they have no presence on the firm's Board of Directors). Next, we get all nonconvertible and non-callable bond and note issues from the New Issues Database of the SDC database. We find 409 firms from the initial set of 743 firms that issued bonds and notes between January 1988 and December 2002. We find that these 409 firms have issued a total of 18,188 bonds over the period under consideration. From this sample, we then delete observations for which the Yield-to-Maturity is not reported in the SDC database. Additionally, we restrict our sample to bond issues that (a) are rated by Moody's, and (b) for which we can find at least the 3-month Government (Treasury) rate in the currency of the bond issue. After these deletions, we end up with a final sample of 11,834 bonds and notes issued by 328 U.S. and ADR firms.

Issue specific information for both samples such as bond yield, maturity, issue size and rating are obtained from the SDC database. Firm-specific balance sheet and income statement variables come from two sources: (a) Worldscope for international firms without an ADR program, and (b) Compustat for U.S. firms and ADRs. Risk free rates are downloaded from Global Insight. 
Table 1 provides information about the bonds (issuing firms by year, country of origin, and currency of issues) in both Sample A and B.

[Insert Table 1]

\subsection{Discussion of the Samples Used}

We use two different samples, each with its own merits and costs that should be fully discussed. The major benefit of using Sample A with 1,072 firms is the depth of its cross-sectional dimension, mixing together firms with different characteristics. One data disadvantage of this sample is that for firms included in the Faccio and Lang (2001) and Claesseans et al. (2000) datasets we only have the ownership observation collected at one point in time. The time-invariance of the ownership data does not present significant economic problems (Claesseans et al. (2002)) since it is well-known that ownership is sticky over a relatively short period of time like the one we use. However, it presents an econometric limitation since we will not be able to use a firm fixed effect specification for this sample that can control for any unobserved heterogeneity across firms.

Sample B with 328 firms has the opposite benefits and disadvantages to Sample A. It has a limited cross-sectional dimension and this can pose limits on any crosssectional methodology used. However, such a sample provides an important data advantage: since we manually collect ownership data for these sample firms over the period 1988 to 2002, we can track changes in ownership and such time-invariance allows us to undertake firm fixed effects methodologies to control for any unobserved heterogeneity.

There is also another, more important, reason for using the U.S. firms and ADRs: this sample is more consistent with our objective of analyzing the impact of external governance, exclusively, on the relationship between blockholders and bondholders. It is reasonable to assume that the extent to which a family can extract private benefits is a function of both internal and external governance. This means that the appropriate sample of firms - those with high standards of internal governance - must be used in order to measure correctly the impact of country-level governance on the relationship between blockholders and bondholders. Using any type of international firm, regardless of its internal governance, can lead to a possible overestimation of debt agency costs, making it 
virtually impossible to disentangle the exact impact of internal governance and external governance.

For this reason, we choose to be conservative in our approach and use firms that should have high levels of internal governance as is the case of firms with an ADR program. Existing literature shows that cross-listing of international firms in the U.S. is one way to achieve a high level of governance by virtue of the listing requirements imposed on the firm. These rules are seen as a mechanism that provides the necessary “certification". Furthermore, Doidge et al. (2005) show that when private benefits are high, the firm's controlling shareholders are found to be less likely to list in the U.S. In this case, higher levels of monitoring, as well as higher standards for transparency and disclosure can severely limit the controlling shareholders' ability to extract private benefits. ADRs provide us with yet another advantage: evidence shows that cross-listing firms are different from non-ADR firms from the same country especially because the former have higher growth opportunities and their shareholders are willing to sacrifice some private benefits of control in order to obtain equity financing. On the other hand, non-ADR firms have shareholders that are only willing to sell their ownership stake at a control premium which is then disproportionately captured (Coffee, 2002).

This evidence shows that the sample of ADR firms we use in this paper should suffer less from the problem of private benefit extraction in general. This should make it harder to find any debt agency costs induced by the presence of a family blockholding. For precisely these reasons we choose to use only Level II or Level III ADRs, together with U.S. firms.

We are aware that focusing on this sample can restrict our analysis in some dimensions and that it may have selection biases. For example, it is not easy to find a family firm that decides to (a) list in the U.S., and (b) then issue bonds. These restrictions, however, should make it more difficult, not easier, to find any agency costs induced by the presence of family blockholding. If anything, the family firms in Sample B should bias the coefficient of the debt agency cost variable towards zero. In this sense, the firms used and the restrictions imposed in defining a family firm are likely to underestimate the actual impact that a family blockholding may cause on debt agency costs. 
Any evidence that external governance matters for debt agency costs in family firms present in Sample B should provide a high level of comfort that the relationship between blockholders and bondholders is indeed influenced by external governance and robust to issues purely generated by firm-level governance.

\subsection{Definition of Family Firm}

We next explain how family firms are defined since our two samples have ownership data from different sources. The basic definition used by Claessens et al. (2000), Faccio and Lang (2001) and ourselves when we manually collect ownership data for U.S. and ADR firms is very similar to the one used by the existing literature: a family firm is one where the founder, or descendents of his/her family (either by blood or through marriage), is a blockholder, either individually or as a group.

The sources of the ownership data differ across firms. Claesseans et al. (2000) and Faccio and Lang (2001) use various sources to get the ownership data, as detailed in their papers. The major data sources for the U.S. and ADR firms are the 20-F forms and proxy statements filed by the firms. We supplement these sources by looking at firms' websites and finding other sources (such as Lexis-Nexis news articles) that can provide information about its history and founders.

Existing literature shows that the above definition of a family firm has to be qualified and clarified in certain cases. Hence, when we manually collect ownership information for U.S. and ADR firms we apply a series of very stringent rules, explained below, to determine the presence of a family blockholder. It is not clear whether Claessens et al. (2000) or Faccio and Lang (2001) apply these restrictive rules. Hence, we will use Sample B to check the robustness of the results to the different definitions of family firms as explained below.

One potential problem with the simple definition used above is that it lumps together family firms that have been in the hands of a family for at least two generations with founder-run firms. The latter, by virtue of these being still in the first generation, are not yet clear whether they can be classified in the family firm category. For example, a founder may cash out his/her ownership stake rather than passing it over to the family and in such case one cannot identify this as a family firm. Given the nature of the sample 
of U.S. and ADRs, formed by the very large and established firms firms, such a problem is less likely to occur. An investigation of the family's ownership in this particular sample shows that almost all family firms are in the hands of second, or later, generations and this fact diminishes the potential problems caused by this issue. Nonetheless we use the firms in Sample B - for which we know whether family blockholding is in the hands of the first or subsequent generations - to check the results when defining a family firm as such when the blockholding is the hands of the second (or subsequent) generation.

Consistent with existing literature, we also apply various rules to determine the meaningful presence of a founding family in some instances, especially in the case of Fortune 500 firms. First, we define a family firm as one that was either founded by a family or where this family was responsible for its early growth (even though, in the latter case, the firm may have been incorporated by a different individual). ${ }^{11}$ Second, consistent with this view of the "founding family", we do not define as family firms those where a person - either individually or through a group or trust - became the largest blockholder through stock-based compensation packages, a management or a leveraged buy-out, or through a spin-off. Third, a family may have founded either the firm in our sample or a predecessor firm that may have made a takeover or a merger in the past and which resulted in the incorporation of the firm in our sample.

Having established the presence of a founding family in the ownership structure is only the first step in our exercise. There is an on-going debate about what really drives the incentives and behavior of a family, even if a family has a blockholding in a firm's ownership structure. Is it the family's ownership that matters or is it its control of voting rights in excess of its cash flow rights? Or, perhaps, should we look at whether the family has a role in the active management of the firm? This issue is particularly important for this paper since our argument of how a family may influence debt agency costs depends on its ability to, on one hand, extract private benefits, and, on the other hand, build trust with financial markets.

In the empirical tests we proceed as follows. We define a firm as being a family firm based on an ownership consideration: hence, irrespective of the size of the family's

\footnotetext{
${ }^{11}$ We have found that this rule is especially important for U.S. firms but not so much for ADRs. In our case, as in the case of Villalonga and Amit (2006), we encounter various examples, such as Cardinal Health and Motorola.
} 
ownership, we define a firm as such as long as the founding family has at least a $10 \%$ of the cash flow rights and is the largest blockholder. ${ }^{12}$ In this way, we have a common cutoff point to define family firms through the three different datasets we use. Recall that while Claesseans et al. (2000) has a cut-off point at 5\%, Faccio and Lang (2001) use a cut-off at 10\%. Moreover, we do not impose any cut-off point for ownership data included in Sample B. Hence, a firm is defined as family-owned if the family blockholder has at least $10 \%$ of the cash flow rights. This basic definition is used for both samples. We use both a dummy variable that takes the value of 1 if a member of the founding family is present and 0 otherwise, and the actual family's ownership stake (in \% of total outstanding shares) in different specifications.

Although the dummy variable has its own advantages and has been used extensively in the literature, it suffers from one significant disadvantage: the incentives and abilities of a family to extract private benefits may be a function of its power inside the firm and this, in turn, is a function of its ownership stake. A dummy variable approach that does not discriminate between a large and small ownership stake of the founding family may introduce important biases. Given these potential problems, we use the family's exact ownership stake (in percentage) as our second way to define a family's presence.

We also calculate the divergence between the family's control rights and cash flow rights (the so-called wedge). Existing literature has found that the incentives to extract private benefits is likely to increase with control-enhancing mechanisms which allow a blockholder to control the firm with very little equity investments. We use a dummy variable that takes the value of 1 if the family blockholding's voting rights are larger than its cash flow rights and 0 otherwise.

Finally, one different way through which a family can exercise its power position is through its presence in the firm's management, irrespective of the actual stake of its ownership. To implement this approach, we use a dummy variable that takes the value of 1 if a family member is in active management and 0 otherwise.

\footnotetext{
${ }^{12}$ Defining a family firm based on the family's ownership is not, however, without potential problems. For example, the percentage of family ownership is typically decreasing in firm size and this may suggest that a potential size effect is being captured, even if appropriate control variables are applied. To address this issue, we also look at the log of the market value of the family's equity stake in the firm, since this might capture the importance of the family's power position but moves away from the ownership percentage concerns.
} 


\subsection{Sample Characteristics}

Table 2 provides descriptive statistics for firm-level characteristics and bond characteristics for the two samples used in this paper.

[Insert Table 2]

Our measure of debt agency costs is obtained using the Yield Spread, calculated as the difference between each bond issue's yield-to-maturity and the 3-month Government (Treasury) bond rate in the currency in which the bond is issued.

Panel A (B) in Table 2 shows that the mean Yield Spread for Sample A (B) is $1.75 \%(1.34 \%)$ with a standard deviation of $1.71 \%(1.60 \%)$. The Yield to Maturity has a mean value of $4.97 \%(6.57 \%)$ and the mean risk-free rate (measured as the 3-Month Government Bond Rate) is 3.39\% (4.64\%). The mean maturity of the bonds issued is 7.47 (6.44) years and the mean value of each bond issue is $\$ 150$ (\$139) millions. There are instances where the Yield Spread is negative. We have analyzed the cases with negative yield spreads and found that this happens mostly because a branch of a multinational firm operating in an emerging market issues a bond in that country whose government's rating is lower than that of the multinational firm. ${ }^{13}$

For a subset of bonds in both samples, specifically for those issued in developed countries, we can get data on the 10-Year Government Bond Yield. It can be argued that for corporate bonds in our samples, with a mean maturity of around 7 years, this type of risk-free rate is better than the 3-month Government Bond Rate. However, we can only find such information for 19 countries in our sample and, very importantly, we cannot find this data for bonds issued in currencies of emerging markets. This means that this type of long-term yield has limited use - given that it will limit the variability of the creditors' rights environments - due to these data limitations. Hence, we shall also use the 10-Year Yield for robustness checks.

Turning to Panel C, we find that, as expected, the firms in Sample A are smaller than those in Sample B. Having said so, there are a number of very interesting differences between family-owned and non-family owned firms in both samples. First, the average

\footnotetext{
${ }^{13} \mathrm{We}$ use all bond issues, including those with negative Yield Spreads, for the base-line estimations. We check the robustness of the results using only the bond issues with non-negative Yield Spreads. The results obtained using the full sample do not change.
} 
family-owned firm has larger long term debt ratio (25.9\% in Sample A) compared to the average non-family firm $(23.8 \%$ in Sample A). This provides some preliminary indication that, since families would want to keep control of their firm, they prefer to finance investments through debt rather than diluting their part through the issue of new equity. In itself, this can potentially make debt agency costs more severe in family firms. We also find that family firms are smaller than non-family firms in both samples. More importantly the Market to Book Ratio of family firms is greater than that of non-family firms (3.154 for family firms versus 2.695 for non-family firms in Sample A). This shows that family firms are perceived to have higher growth potential than non-family firms and is consistent with recent empirical evidence for U.S. firms. We find that $28 \%$ of the firms in Sample A and 23\% of Sample B have a founding family in their ownership structure and the average family ownership amounts to $42 \%$ in Sample A and $27 \%$ in Sample B. Finally, the founding family is present in active management in almost $65 \%$ of the family firms in Sample A and 55\% of the family firms in Sample B.

Panel B also shows the ownership stake of non-family blockholders for firms in Sample B. We obtain data on non-family blockholders (defined as a firm or person that owns at least $5 \%$ of the outstanding shares) in general and also on non-family inside blockholders only for Sample B. The presence of such blockholders is smaller in family firms compared to non-family firms (their average (median) stake is $12.2 \%(3.1 \%)$ in family firms and $18.4 \%(12.3 \%)$ in non-family firms). The same applies to non-family inside blockholders (their average (median) stake is $2.5 \%(0 \%)$ in family firms and $6.2 \%$ $(2.8 \%)$ in non-family firms). This implies that any monitoring role that such blockholders could have - assuming that they carry out such a task - is very much limited in family firms. Having said this, it needs to be seen whether having a non-family blockholder inside the firm, especially if it has an active management role, influences the behavior and incentives of the family. Finally, Panel B also shows that family firms tend to be more present in countries with lower external governance rules compared to non-family firms. 


\subsection{Measuring the Investor Protection Environment}

Consistent with existing literature, we capture the investor protection environment through various well-established indices. Legal Environment (henceforth "Legality"), proposed by Berkowitz, Pistor, and Richard (1999), is derived from a principal components analysis of the covariance matrix from the efficiency of the judiciary system, rule of law, corruption, risk of expropriation, and the risk of contract repudiation. The Creditors' Rights Index, developed by La Porta et al. (1998), is an aggregate measure of creditor rights and measures how well creditor rights are protected under bankruptcy and reorganization laws. The Judicial Efficiency variable is measured as the assessment of the efficiency and the level of integrity of the legal environment and the way such characteristics influence business. Rule of Law is the law and order tradition in the country and is obtained from La Porta et al. (1998).

The ideal index should have two characteristics: first, it should measure the way creditors specifically, rather than investors in general, are protected in a specific country, and, second, it should provide a comprehensive picture of all the factors that contribute to investor protection, both the presence of laws and their enforcement. None of the indices mentioned above meet these two requirements.

The two indices that come closest to our objective are Legality and Creditors' Rights. The only disadvantage of the former is that it gives a measure of the protection of investors in general, rather than creditors' protection while its advantage is that it covers both existence and enforcement of laws. On the other hand, the Creditors' Rights Index, while covering specifically the laws protecting creditors, does not consider the enforcement factor. As expected, the correlation between various indices is high, providing comfort that results are not driven by the use of a specific index. ${ }^{14}$

We use the Legality Index and Creditor Rights Index as our base case measures in different specifications. We analyze the sensitivity of our results to using other Indices mentioned above as well.

\footnotetext{
${ }^{14}$ For Sample B, the correlation between the Legality Index and the Creditors' Rights Index is 0.91 at the bond issue level (all 11,834 observations), 0.94 at the firm level (328 firms), and 0.93 at the country level (28 countries). Similar correlations are observed in Sample A as well.
} 


\subsection{Variables Used and Econometric Methodology}

We next discuss the way we measure debt agency costs and the variables that have been found to influence corporate bond yields and for which we need to control.

Our dependent variable is the Yield Spread calculated as the difference between each bond issue's yield-to-maturity and the 3-month Government (Treasury) bond rate in the currency in which the bond is issued. One advantage of using the bond's yield to maturity at the time of issue rather than yields to maturity from the secondary market is that we can measure the yield spread free from liquidity premium concerns. Ideally, in calculating the Yield Spread we should have the same maturity length for each bond and the risk free rate proxy. However for some currencies long-term Government bond rates are not available. As a result, the yield spread we measure is upward biased and includes a term premium which should increase with maturity and varies cross-sectionally for different currencies. We explicitly control for this bias in our regressions by using (a) each bond's maturity as one of the independent control variables, and (b) employing a country, and currency fixed effects methodologies. We also run the basic regressions on a sample of bonds issued in currencies for which we know the 10-Year Government Bond Yield to check the results' robustness. In this case the Yield Spread is calculated as the difference between each bond issue's yield-to-maturity and the 10-Year Government bond rate in the currency in which the bond is issued.

Table 3 describes the independent variables used. We divide these variables into four main groups: (a) bond-level characteristics, (b) firm-level characteristics, (c) firmlevel governance measures, and (d) country-level governance measures.

\section{[Insert Table 3]}

Bond Rating is a major determinant of the credit risk of each bond issue. We transform the bond's Rating into a cardinal value, following values to the ordinal Moody's rating categories in the following way: $\mathrm{Aaa}=1, \mathrm{Aa}=2, \mathrm{~A}=3, \mathrm{Baa}=4, \mathrm{Ba}=5, \mathrm{~B}=6$, and below $\mathrm{B}=7$. A higher numerical value for rating implies lower credit quality, so we expect a negative relation between the bond rating and yield spreads. We also use both the log of the Ratings and the squared term of the Ratings to control for non-linearities in bond ratings. 
One potential issue that should be considered is that Bond Ratings could, in the first place, incorporate the impact of family ownership and any risk that may arise from such ownership. Hence, if it is the entire impact that family ownership has on debt agency costs that we want to measure then Bond Ratings should not feature as an independent variable. Including Ratings would lead to an underestimation of the real impact of family ownership.

We use the natural logarithm of the bond's Maturity as a proxy for both credit risk and interest rate risk. Longer Maturity issues have higher default probabilities and also carry a higher term premium according to our Yield Spread definition. Issue Size is defined as the natural logarithm of the dollar proceeds of the bond issue. More public information is generated with bigger size issues and there is less asymmetric information in such issues and they are also expected to have more liquidity in the secondary market. Hence we expect a negative relation between the Yield Spread and Issue Size.

Long-Term Debt Ratio measures firm's leverage and controls for default risk in addition to bond ratings. Firm Size is defined as the natural logarithm of total assets. Larger firms should have better access to capital markets and might borrow at more favorable terms with respect to small firms. Market-to-Book Ratio proxies for the borrower's growth opportunities. Faster growing firms may be better able to meet future debt payments, but they are also associated with higher risk. Alternatively, Firm Size and Market-to-Book ratio can be interpreted as risk proxies in the spirit of Fama and French (1996). Operating Margin measures firm performance. Firms with higher operating income are associated with lower future default risk.

We also use Industry Dummies, where appropriate depending on our econometric specification, to control for industry-specific factors that may influence the cost of debt, and Year Dummies, to control for any time-series movements that may have occurred in the Yield Spreads. Since the risk-free rate fluctuate significantly over the period under consideration, with periods characterized with very high risk-free rates (like the early 1990s) and others with historically low risk-free rates (like the late 1990s and early part of this decade), we also include the country's average annual risk-free rate as an independent variable to check the robustness of results. 
Where appropriate, given the type of specification we run, we also use three country-level control variables to control for the level of development of the financial market within a country (Ratio of Stock Market Capitalization to $\mathrm{GDP}^{15}$ ), the level of investor protection (Legality Index), and the level of protection of bondholders (Creditors' Rights Index). It should be noted that the first measure changes across years, but the second and third measures are time invariant.

We carry out two types of regression models to measure the impact of external governance on the family-bondholders relationship. First, we use all bond issues in a regression that has (a) the Family Ownership (Family Dummy) variable, and (b) an interactive variable between the Family Ownership (Family Dummy) variable and the Legality Index or the Creditors' Rights Index as follows:

Yield Spread $_{\mathrm{j}, \mathrm{i}, \mathrm{c}, \mathrm{t}}=\alpha$ Family $_{\mathrm{i}, \mathrm{c}, \mathrm{t}}+\beta\left[\right.$ Family $_{\mathrm{i}, \mathrm{t}} \mathrm{x}$ Protection $\left._{\mathrm{c}}\right]+\delta \mathrm{Y}_{\mathrm{j}, \mathrm{i}, \mathrm{c}, \mathrm{t}}+\lambda \mathrm{X}_{\mathrm{i}, \mathrm{ct}}+\gamma \mathrm{Z}_{\mathrm{c}}+\varepsilon_{\mathrm{i}, \mathrm{c}, \mathrm{t}}$

where the yield spread is the difference between each bond's yield-to-maturity, $\mathrm{j}$, issued by firm i, from country c, at time $t$, and the 3-month Government bond rate; Family is a measure of family's presence (ownership stake or dummy variable) in each firm; Protection is the level of country-level governance in each country c; $\mathrm{X}$ is a set of firm-specific control variable; $\mathrm{Y}$ are bond-level characteristics; and $\mathrm{Z}$ are country-level control variables. In this type of regression analysis, the impact of external governance on debt agency costs will be the total effect of the two coefficient estimates, $\alpha$ and $\beta$.

Second, we recognize that we need to address two important factors in our regression methodology. First, family firms may be younger than other firms, with higher asymmetric information problems, and hence they may be more financially constrained than non-family firms. Second, countries with more developed financial markets may also have better investors' protection and firms in such an environment may have access to cheaper finance. We control indirectly for these two factors in (1) above, but we also use the following model to explicitly take them in consideration:

\footnotetext{
${ }^{15}$ Data on Stock Market Capitalization is obtained from the International Financial Statistics database of the International Monetary Fund with the exception of Taiwan. We obtain data for the latter from the Taiwan Stock Exchange.
} 


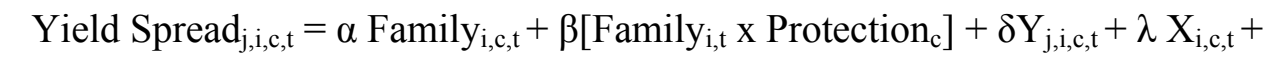

$\xi\left[\mathrm{X}_{\mathrm{i}, \mathrm{c}, \mathrm{t}} \mathrm{X}\right.$ Protection $\left._{\mathrm{c}}\right]+\gamma \mathrm{Z}_{\mathrm{c}}+\zeta\left[\right.$ Family $_{\mathrm{i}, \mathrm{t}} \mathrm{x}$ Financial Development $\left.\mathrm{c}\right]+\varepsilon_{\mathrm{i}, \mathrm{c}, \mathrm{t}}$

where the variables have the same description as in equation (1) above and Financial Development is the ratio of stock market capitalization to GDP.

We carry out two types of regression methodologies. First, we use a crosssectional regression where we use one bond-issue observation for each firm. This is the most natural way to test our hypotheses since the argument is essentially a cross-sectional one. We obtain the observation in three different ways: (a) a random observation, (b) the first bond issued, and (c) the last bond issued made by each firm. Second, we use the panel dimension of our dataset with the appropriate fixed effects (country, industry, country and industry, firm, and currency fixed effects).

The panel methodology presents a number of econometric issues that have to be fully addressed. First, there may be unobserved heterogeneity at the country, industry or firm level and which calls for fixed effect specifications. We run four different fixed effect specifications using both samples: (a) country fixed effects, (b) industry fixed effects, (c) currency, and (d) country and industry fixed effects. However, a firm fixed effects specification presents its own challenge given by the ownership data and the way the family presence is captured. For most firms in Sample A, the family's cash flow rights (and voting rights) are fixed through time and this rules out a firm fixed effects specification. There are two different explanations for this limitation: first, ownership stakes are very sticky through time, and, second, we only have one ownership observation for firms in the Claessens et al. (2000) and Faccio and Lang (2001) datasets. In this case, Sample B comes to the rescue since this problem is less severe ${ }^{16}$ since we $^{-1}$ capture the family presence through the family's cash flow rights ${ }^{17}$ through a long period.

Second, a number of firms in our sample, especially U.S. firms, undertake repeated bond issues while some other issuers may go to the bond market only once. This calls for adequate controls for clustering of issues.

\footnotetext{
${ }^{16}$ The time period covered is much longer, allowing for ownership to change, and we collect the ownership information on a yearly basis.

${ }^{17}$ The firm fixed effect specification cannot be used when we capture the family presence through a dummy variable because there is no variability in the dummy variable.
} 
Third, we also have to consider the potential problems encountered in estimating (1) and (2) above in a panel regression as mentioned by Bertrand, Duflo, and Mullainthan (2004). In our case the problem may not originate from our dependent variable (which is not positively serially correlated), but rather because the interaction variable may change very little within a country over time. We solve this problem using two solutions: first, the clustering correction at the firm level should produce consistent standard errors, and second, as suggested by Bertrand et al. (2004) we collapse the data to a single observation for each firm, using the mean and the median values of all the variables and run a cross-sectional regression.

\section{Section 4.0 Results}

We next discuss the main results found from the various cross-sectional and fixed-effects models we use. The base case results, using the family ownership and the interactive term between family ownership and external governance measure in a crosssectional model where only one observation per firm is used, are shown in Table 4. We use a random bond issue observation for each firm in the first and second column, the first bond issue observation in the third column and the last bond issue observation in the fourth column.

[Insert Table 4]

Recall that from our hypotheses, we do not have any firm expectation about the sign of the coefficient estimate of the family ownership. On the other hand, according to the monitoring hypothesis, we should expect a negative sign for the coefficient estimate of the interactive variable since debt agency costs of family firms should be lower (higher) than for non-family firms incorporated in countries with strong (weak) external governance.

We look at the impact generated by the two sets of variables together: (a) Family Presence (Ownership or Dummy), and (b) Family Presence x Legality, and Family Presence x Creditors' Rights Index. When we analyze the Family Presence individually, we find that the presence of a family in itself increases the debt agency costs. However, the interaction term between the Family Presence and Legality (or Creditors' Rights Index) is negative, meaning that the better the investors' protection regime the more will 
the family's presence decrease the debt agency costs. In order to find the exact impact of the family blockholding across the different investor protection environments we need to get the net effect of these two individual variables. Doing so, we find strong evidence that the presence of a founding family in low creditors' protection environment is associated with higher cost of debt while in higher protection environments having a family in the ownership structure leads to lower debt costs.

Analyzing the first column in Table 4 we can notice that a family firm incorporated in a country with a high Legality Index measure (with a Legality Index measure of 21.96 representing the mean of the Legality Index, 19.52, plus one standard deviation, 2.43) pays 31 basis points less than a non-family firm in the same Legality environment. Applying the same approach when using the Creditors' Rights Index, we find that a family firm pays 23 basis points less than a non-family firm in the same Creditors' Rights environment (an Index measure of 2.39). On the other hand, a family firm incorporated in a country with a low Legality Index measure (a country with a Legality Index measure of 17.09) pays 45 basis points more than a non-family firm in the same Legality environment. ${ }^{18}$ Using the Creditors' Rights Index, we find that a family firm pays 35 basis points more than a non-family firm in the same Creditors' Rights environment. Considering that the mean Yield Spread is $1.75 \%$ (with a median of $1.64 \%$ ) the economic impact of a family ownership is quite significant. It is also important that the economic significance of these results do not change much when using either the Legality Index or the Creditors' Rights Index. It is also important to note the similarity in the magnitude of the impact of the family blockholding when using two different measures of investors' protection.

Likewise, if we use the ownership stake to capture the Family Presence, rather than a dummy variable, we find similar results. The results are shown in the fourth column (using the last bond issue) and the fifth column (using a random bond issue). Considering the fourth column (where we use the Creditors' Rights Index), we find that a family firm with at the mean level of Family Ownership (a stake of 42.3\%) originating from a country with low Creditors' Rights Index (Legality Index) measure will pay 49

\footnotetext{
${ }^{18}$ This analysis assumes that the family's ownership stake is the same in both the low and high Legal environments.
} 
basis points more than a family firm originating from a country with a high measure. ${ }^{19}$ This result, however, is obtained assuming the same level of family ownership in low and high legality countries. These results show that the family's ownership stake is an important factor in the mechanism through which the family can influence the agency costs.

We have information on the ratings of a subset of bond issues and we get a random bond issue observation for 659 firms. The results are shown in columns six and seven. The coefficient for the Bond Ratings is positive and highly significant. The introduction of such a variable has two important impacts on our results. First, it decreases the magnitude and statistical significance of the Family Presence and the Family Presence interacted with the country-level governance. Second, it has a similar impact on all the other control variables included in the regressions. Importantly, even after the inclusion of Ratings we continue to find the presence of a family blockholder to be statistically and economically significant and the same can be said for the interaction term. Hence, the inclusion of Ratings leaves unaffected the results confirming the monitoring hypothesis. We now find that a family firm incorporated in a country with a high (low) Creditors' Rights Index measure pays 10 (37) basis points less (more) than a non-family firm in the same environment. The net effects using Bond Ratings are smaller than those we obtain without ratings and their statistically significant decreases relative to the previous results. This result implies that Bond Ratings take into consideration the impact of the ownership structure but they do so imperfectly because the inclusion of ratings do not remove the impact of family blockholdings.

In Table 5 we show the results from the panel regressions with all the 8,835 bond issues using various fixed effects specifications. Column 1 has industry fixed effects, column 2 has country fixed effects and columns 3-6 have country and industry fixed effects.

\section{[Insert Table 5]}

\footnotetext{
19 The calculation is done in the following way. The cost of debt for the average family-owned firm, where the family's ownership stake is $42.3 \%$, operating in a country with a low Creditors' Rights Index measure with a value of 0.906 is $[(0.0161 \times 42.3)+(-0.0078 \times 42.3 \times 0.906)]=0.3821$. The cost of debt for the same type of family-owned firm operating in a country with a high Creditors' Rights Index measure with a value of 2.394 is $[(0.0161 \times 42.3)+(-0.0078 \times 42.3 \times 2.394)]=-0.1089$.
} 
Again we find that the net impact of the family presence is statistically and economically significant similar to the results using the cross-sectional regression results in Table 4. For example, if we look at the third column where we use the Family Dummy and country and industry fixed effects, we find that a family firm incorporated in a country with a high (low) Legality Index measure pays 40 (71) basis points less (more) than a non-family firm in the same environment. In Table 5 we also show the results with the country and industry fixed effects and the inclusion of bond ratings which gives us 6,015 bond issue observations. Consistent with the results in Table 4 when we included ratings, we also find that the net impact of the family presence and the country governance is diminished.

We use Sample B, with U.S. and ADR firms, as an out-of-sample test in Table 5. Column 6 shows the results using a firm fixed effects methodology and column 7 shows a country and industry fixed effects methodology. For the firm fixed effect methodology we are constrained to use the Family Presence only through the ownership stake and cannot use the dummy variable. One may argue that the results using Sample A may be driven (at least partly) by different internal governance mechanisms which may overestimate the debt agency costs. The same cannot be said about Sample B because all the 328 firms in this sample have high, and very comparable, internal governance mechanisms. The coefficient for the Family Presence is positive while the one of the interaction variable is negative and both are statistically significant. This means that the impact of the family blockholder and the country-level governance is also obtained even when using a much more restrictive sample and one that does not have problems with different internal governance. Looking at the economic significance of the net impact, we find that a family firm incorporated in a country with a high (low) creditors' protection pays 10 (21) basis points less (more) than a non-family firm in the same Legality environment. ${ }^{20}$ Considering that the mean Yield Spread for Sample B is $1.34 \%$ the economic impact of a family ownership is quite significant. It is also important that the economic significance of these results do not change much when using either the Legality Index or the Creditors' Rights Index. As expected, however, the net effect is considerably smaller for this sample compared to Sample A implying that internal governance was, at least in part, contributing to the results we found for Sample A.

\footnotetext{
${ }^{20}$ These impacts are obtained using the firm fixed effects specifications.
} 
We conjectured that one crucial aspect of the relationship between the presence of the founding family and the cost of debt is not just the mere presence of a family but rather the magnitude of the shareholding. An important insight from Tables 4 and 5 is that the family's presence in both low and high investors' protection environment has no impact when the ownership stake is very low. This result suggests that the actual ownership stake level is an important aspect of the relationship and the impact on agency costs is monotonically increasing with family ownership.

The impact that the investor protection environment is found to have on the behavior of the family behavior is quite different than that found by existing literature. For example, Lins (2003) finds in favor of a presence of large blockholders, especially as an effective mechanism in the presence of management's control rights. In this paper we find a more complex story where, at least for bondholders, a large blockholder's impact is considered as a positive development in high investors' protection environments but judged as negative in low investors' protection regimes.

Considering Tables 4 and 5 together, we can see that most of the signs of the control variables are consistent with our expectations and with existing literature. We want to highlight both the results for Ratings and the Log Maturity, both of which are statistically significant, for various reasons. As expected, lower Rating lead to higher cost of debt. Our main results are robust to different specifications of the Rating variable.

The Log Maturity variable has the expected sign and is also statistically significant. The latter result is interesting in view of the fact that for some existing papers the Log Maturity is not found to be significant (Miller, 2002, Anderson et al., 2003). We suspect that this variable is significant in our case mainly because it is accounting for the fact that our bonds' maturities are not perfectly matched with the maturity of the risk free rate as explained above. Finally, the riskier the firm, as captured by the Long-Term Debt Ratio, the higher the cost of debt while the higher profitability, as captured by the Operating Income/Total Assets, the lower the cost of debt.

Our results are obtained after controlling for country specific control variables, through country dummy variables, and the Ratio of Stock Market Capitalization to GDP. The last variable is important in our research design since it has been used by the literature to proxy for the development of capital markets. Firms incorporated in highly 
developed capital markets should have access to cheaper finance. It should be mentioned, though, that countries with highly developed markets should also have higher standards of investor protection and hence Stock Market Capitalization to GDP Ratio can be highly correlated with the investors' protection measures.

We carry out various robustness checks on the various specifications shown in Tables 4 and 5. First, we use a currency fixed effect specification using the currency in which the bond is issued. Second, for each fixed effect specification we introduce the country's average annual corporate bond market premium as an independent variable to control for the fluctuations in the riskiness of bonds issued over the period. Third, for each fixed effect specification we run the specification using the log of the Bond Ratings or the squared term of the Bond Ratings. We find that our results hold in each of the robustness checks we undertake.

In Table 6 we present the results from the panel data regression of the second specification. $^{21}$

\section{[Insert Table 6]}

The results shown in Table 6 confirm the impact of family blockholdings in different protection environments even after we explicitly control for the fact that family firms in low legality and creditors' protection environment may be more financially constrained relative to those in better legality environments. This result is obtained both for Sample A (columns 1 -5) and Sample B (columns 6 - 8). The main impact of the introduction of the two new variables, $\left[\mathrm{X}_{\mathrm{i}, \mathrm{c}, \mathrm{t}} \mathrm{x}\right.$ Protection $\left._{\mathrm{c}}\right]$ and $\left[\right.$ Family $_{\mathrm{i}, \mathrm{t}} \mathrm{x}$ Financial Development $_{\mathrm{c}}$ ], is that the resulting net impact of the family blockholding itself decreases but is not washed away. In certain specifications, however, the Family Presence variable has less statistically significance compared to the estimates before. An interesting result in Table 6 is that the coefficient of the Family interacted with Financial Development variable lacks any statistical significance (although its sign is consistent with expectations). Hence we can say that what is driving our results is not the country's financial development but rather the level of protection allowed to creditors. There is a clear economic difference between a

\footnotetext{
${ }^{21}$ For the sake of brevity, we do not report the coefficient estimates and statistical significance of the firm specific control variables since they have the same economic meaning as shown in Tables 4 and 5. Full results are available from the authors.
} 
country's financial development and creditors' protection, even though they may be heavily correlated, and disentangling one effect from the other is important.

A major issue that has rightly received substantial attention is whether the family has any managerial role. Such a role can have two possible implications. It can either reduce the classic owner-manager agency conflict or, as in Burkart, Panunzi and Shleifer (2003) it can harm the firm since hired managers could have better skills and produce better performance than the founding family or its heir/s. However, the evidence so far is mixed. ${ }^{22}$ In our case, it can be argued that the family's incentives are clearer when the family has a managerial role compared to when the management is in the hands of professional managers.

We use the variable Family in Management (dummy variable that takes the value of 1 if a family member is in active management and 0 otherwise) to test the robustness of our results to the inclusion of the family's managerial role.

\section{[Insert Table 7]}

The results in Table 7, both for Sample A (columns 1 - 4) and Sample B (columns 5 and 6) show that having a family member in the firm's management leads to more severe debt agency costs in both low and high legal environments. However, the impact of the family ownership, and its interaction with the creditors' protection environment, does not disappear. What seems to be happening is that any family's managerial role absorbs some of the impact that before was being reflected in the Family Presence. Importantly, total debt agency costs increase over and above that implied by just the presence of the family blockholder.

A potentially important variable is the wedge of family ownership. Wedge measures the difference between the ownership rights and the cash flow rights of the blockholder. One of the objectives of using a pyramidal structure is to achieve the widest possible wedge because a blockholder can control a firm without actually having the majority of the cash flow rights. The larger the difference between these two different rights the more likely is expropriation to take place by the blockholder. We expect that

\footnotetext{
${ }^{22}$ See Palia and Ravid (2002), Adams, Almeida and Ferreira (2004), Fahlenbrach (2004), Smith and Amoako-Adu (1999), Perez-Gonzalez (2001) and Villalonga and Amit (2006).
} 
the higher the wedge, the more protection would be required by bondholders, especially when lending money in low legal environments. We include wedge in our specification and the results are shown in column 7 (wedge alone) and column 8 (wedge together with the family management). We find that, although wedge has the right sign, it is never statistically significant. On one hand, this is a surprising result because a family blockholder with a wedge between cash flow rights and voting rights can more easily use its control over the firm to extract private benefits or engages in strategies that create conflicts with bondholders. On the other hand, Faccio and Lang (2001) show that, although anecdotal evidence about wedge is that it is a pervasive tool used by blockholders, in reality only few companies in their sample use this practice. In fact, only about $27 \%$ of the firms in Faccio and Lang (2001) have a difference between cash flow rights and voting rights confirming that the practice of using control enhancing mechanisms is not as pervasive as usually thought.

Finally, we want to investigate two remaining questions related to the different nature of different types of blockholders (family versus non-family) and their impact on debt agency costs. First, does a family blockholding have a different impact on debt agency costs compared to other types of blockholdings, namely institutional, outside and inside blockholders? We have already argued that the founding family's main characteristics - namely the lack of diversification in its investments, long term commitment and the association between its reputation and that of the firm - make this particular blockholder different than institutional blockholders.

Second, since some family firms may also have non-family blockholders in the ownership structure, we investigate whether the family's behavior changes when it is not the only blockholder inside the firm. It is possible that the family's power position will be different in such a situation where it can be disciplined by another blockholder. In such a case, there will be two different monitoring mechanisms overseeing the family: (a) external governance, and (b) the presence of a non-family blockholder.

\section{[Insert Table 8]}

We have detailed data on the type of institutional blockholders, and whether they occupy any role in the firm's management, for Sample B only. 
Table 8 (columns 1-6) shows the results with the baseline specification in equation (1) with the presence of Non-Family Blockholders, specifically three types of such blockholders: first, any type of Non-Family Blockholder, second, a Non-Family Blockholder that is in active management, and, third, a Non-Family Blockholder that has no role in the firm's management. The specification uses a dummy variable to capture the blockholder's presence. ${ }^{23}$ We define a firm as owned by a Non-Family Blockholder if such a blockholder, with at least $5 \%$ of the cash flow rights, is the largest blockholder in the ownership structure.

The results show that, unlike family blockholders, none of these Non-Family Blockholders produce any statistically significant impact on debt agency costs. Equally important, even the Non-Family Blockholders involved in the firm's active management have no impact on such costs. Furthermore, any impact that Non-Family Blockholders may have does not change with the Creditors' Rights Index (or Legality measure). Considered together, these results confirm that there is a significant difference between different types of blockholders in terms of both incentives and behavior, and the final impact on agency costs.

We next investigate whether the behavior of Family Blockholders changes when they find themselves in the presence of Non-Family Blockholders. Recall that firms are defined as family-owned when the Family Blockholder is the largest blockholder. This group of family-owned firms contains two distinct groups: (a) firms where the Family Blockholder is the only blockholder in the firm's ownership structure, and (b) firms where the Family Blockholder is the largest blockholder but co-exists with one or more Non-Family Blockholders. We want to investigate whether the behavior of Family Blockholders in the first case is different than in the second case because of the discipline that can be exercised by Non-Family Blockholders. We use a specification with two dummy variables. First, a dummy variable that denotes the presence of the Family Blockholder (hence a family firm), and, second, a dummy variable that denotes the presence of a Family Blockholder together with a Non-Family Blockholder (Family Presence Together with Non-Family Blockholder).

\footnotetext{
${ }^{23} \mathrm{We}$ have also run the results using the ownership stake. The results are qualitatively the same.
} 
Columns 7 and 8 in Table 8 show the results. The coefficient for the Family Blockholder is positive as before and statistically significant while the coefficient of the interacted variable (Family Presence x Creditors' Rights) is negative and statistically significant. More importantly, the coefficient of the dummy variable that captures the

presence of Family Blockholder alongside Non-Family Blockholders is negative but lacks statistical significance. There are a number of implications from such results. First, we find that the family's impact on debt agency costs continues to be robust even after the inclusion of other types of blockholders in the firm's ownership base. Second, the fact that the coefficient of the variable Family Presence and Non-Family Blockholder Presence is not statistically significant shows that the family's behavior does not change in the presence of other blockholders. This can happen because Non-Family Blockholders do not undertake enough monitoring and therefore do no discipline Family Blockholders.

\subsection{Further Robustness Checks and Endogeneity Issues}

We have carried out several robustness checks besides those we have detailed above. We have addressed the issues raised by Bertrand et al. (2004) for the type of methodology used in this paper by collapsing the data to a single observation for each firm, using the mean and the median values of all the variables and run a cross-sectional regression. The results are qualitatively the same as those reported in Table 4.

More importantly, we also run the analysis using, as the dependent variable, the Yield Spread calculated as the difference between each bond issue's yield-to-maturity and the 10-Year Government Bond rate in the currency in which the bond is issued. In this way we come closer to matching the bonds with the most relevant risk-free rate. We run these specifications on a reduced sample since we can only find data on the 10-Year Government Bond rate for 19 countries. We find that the results are qualitatively similar to those reported in Tables 4 and 5. We still find evidence in favor of the monitoring hypothesis, but there are some notable differences. In these specifications, the statistical and economic impact of the Family Presence is reduced (while remaining significant) and this also applies to Maturity, Ratings and Subordination.

Finally, we want to address the issue of endogeneity in this research project. It is reasonable to argue that the country-level governance where a firm is incorporated is 
largely exogenous. This consideration should reduce significantly any concern about the endogeneity in our research design.

However, it could be argued that founding families may choose to be owners of particular types of firms where it is easier for them to extract and consume private benefits, resulting in the expropriation of bondholders. In this case, family ownership and debt agency costs may be endogenously determined. Alternatively, families may choose less risky firms as a counteracting measure for the undiversified nature of the family's holdings.

In our opinion, these issues are not very plausible in this research set-up. The endogeneity issues mentioned above can very well take place when considering a single country, but we fail to see how these considerations can be applied across-countries. For endogeneity to be a concern here, it has to be the case that the nature or type of the industry (or firm) that is attractive to a family, because of the potential extraction of private benefits or because of its low risk factor, has to change with the creditors' rights environment. If extraction of private benefits is driven by, for example, technology opacity then the propensity to extract private benefits should not change with the creditors' protection environment. Applying this concept to our research question, for this type of endogeneity to be an issue it has to be argued that the same low risk firm/industry (or one with high private benefit extraction possibility) leads to lower debt agency costs in high Legality countries but higher costs in low Legality countries. Existing literature does not show that this is the case.

\section{Section 5. Conclusion}

In this paper we investigate whether the presence of a founding family mitigates or exacerbates debt agency costs under different creditors' protection environments. Often, founding families are in a very uncommon position of power where, through the complex mechanisms of pyramids and cross-holdings, their control rights are significantly higher than their cash flow rights. This position of power raises questions so far not addressed by the literature - on how families are disciplined and monitored. We wanted to investigate how families behave when they find themselves in such power 
position. Do founding families behave differently in different investors' protection environments?

There are two competing hypotheses about the relationship between family firms and debt agency costs. The first one states that, if external governance matters, then founding families should mitigate debt agency costs operating in high financial discipline environments - through effective control of the negative effects coming from the family's position and thus allowing the family's positive effects to emerge - but should exacerbate these agency costs in low financial discipline environments - by virtue of the absence of effective controls over the family's power. Hence, we would expect debt costs to be lower (higher) for family firms (compared to non-family firms) in high financial discipline environments (low financial discipline environments).

On the other hand, if external governance mechanisms do not matter, then family firms - through their ability to build long-term relationships with bondholders - should mitigate the agency costs of debt in both high and low financial discipline environments.

Using international bond issues in two different samples we find evidence that family firms' debt costs vary with creditors' protection. We found that family firms suffer from higher debt costs when investors' protection is low but benefit from lower debt costs when investors' protection is high. Besides the direct impact of the family blockholding, these results also show that bondholders act rationally and take into consideration any agency conflicts that certain types of blockholders can generate. Hence they ask for a higher return on bonds issued by family firms in countries where financial discipline and creditors' protection are low.

Our results are robust to (a) different measures of the founding family's presence, and (b) various econometric specifications. Finally, we also find that family blockholding has a different impact on debt agency costs relative to institutional (whether outside or inside) blockholders. In fact, we find no debt agency costs induced by the presence of non-family blockholding, whether they are in active management or not. These results confirm the view that the way non-family blockholders behave is different than that of family blockholders.

This paper shows that "who monitors the family" (La Porta et al., 1999), in terms of external governance, is a crucial issue in determining the effective impact of family 
blockholdings. Our evidence also shows that the firm's ownership and the investors' protection rules are factors that are taken into consideration by investors in pricing corporate bonds. 


\section{References}

Adams, R. B., Almeida, H., and D. Ferreira, 2004, Understanding the relationship between founder-CEOs and firm performance, Working Paper, New York University.

Anderson, R.C., S.A. Mansi, and D.M. Reeb, 2003, Founding family ownership and the agency cost of debt, Journal of Financial Economics, 68, 263-285.

Backman, Michael, 1999, Asian Eclipse: Exposing the Dark Side of Business in Asia, Wiley: Singapore.

Bagnani, E., Milonas, N., Saunders, A., and Travlos, N., 1994, Managers, owners, and the pricing of risky debt: An empirical analysis, Journal of Finance, 49, 453-478.

Barnea, A., Haugen, R., and Senbet, L., 1981, An equilibrium analysis of debt financing under costly tax arbitrage and agency problems, Journal of Finance, 36, 569-582

Bebchuk, L, 1994, Efficient and inefficient sales of corporate control, The Quarterly Journal of Economics, 109, 957-994.

Berkowitz, Daniel, K. Pistor, and J. Richard, 2003, Economic development, legality and the transplant effect, European Economic Review, 47, 165-195.

Bertrand, M., Duflo, E., and Mullainathan, S., 2004, How much should we trust differences-in-differences estimates?, The Quarterly Journal of Economics, 119, 249-275.

Burkart, M., F. Panunzi, and A. Shleifer, 2003, Family firms, Journal of Finance, 58, 2167-2202.

Claessens, Stijn, Simeon Djankov, and Larry H. P. Lang, 2000, The separation of ownership and control in East Asian corporations, Journal of Financial Economics, 58, 81-112.

Claessens, Stijn, Simeon Djankov, Joseph P. H. Fan, and Larry H. P. Lang, 2002, Disentangling the incentive and entrenchment effects of large shareholdings, Journal of Finance, 57 (6), 2741-2772.

Coffee, J., 2002, Racing towards the top?: the impact of cross-listings and stock market competition on international corporate governance, Columbia Law Review 102, 17571831.

Demirguc-Kunt, Asli and Ross Levine, 1999, Bank-based and market-based financial systems: cross-country comparison, mimeo, World Bank.

Demsetz, H., and K. Lehn, 1986, The structure of corporate ownership: Causes and consequences, Journal of Political Economy, 93, 1155-77. 
Demsetz, H., and Belen Villalonga, 2001, Ownership structure and corporate performance, Journal of Corporate Finance, 7, 209-233.

Doidge, C.G., Karolyi, A., Lins, K.V., Miller, D.P., and Stulz, R.M., 2005, Private benefits of control, ownership, and the cross-listing decision, Working Paper, Ohio State University

Durnev, Art, and E. Han Kim, 2005, To Steal or Not to Steal: Firm Attributes, Legal Environment, and Valuation, Journal of Finance, 60 (3), 1461-1493.

Faccio, Mara, Larry H.P. Lang, and Leslie Young, 2001, Dividends and expropriation, American Economic Review 91(1), 54-78.

Faccio, Mara, and Larry H.P. Lang, 2002, The ultimate ownership of Western European corporations, Journal of Financial Economics 65, 365-395.

Fahlenbrach, R., 2004, Founder-CEOs and stock market performance, Working Paper, Wharton School, University of Pennsylvania.

Filatotchev, I., Mickiewicz, T., 2001. Ownership concentration, "private benefits of control", and debt financing, Unpublished Working Paper, University of London and University College, London, England.

Gibbs, Paul, 1993, Determinants of corporate restructuring: The relative importance of corporate governance, takeover threat and free cash flow, Strategic Management Journal, $14,51-68$.

Gillan, S.L., and L. T. Starks, 2000, Corporate governance proposals and shareholder activism: the role of institutional investors, Journal of Financial Economics 57, 275-305.

Gomez-Mejia, L. Nunez-Nickel, M., Gutierrez, I., 2001, The role of family ties in agency contracts, Academy of Management Journal 44, 81-95.

Grossman, S. and O. Hart, 1988, One share-one vote and the market for corporate control, Journal of Financial Economics, 20, 175-202.

Harris, M and A. Raviv, 1990. Capital structure and the information role of debt, Journal of Finance, 45, 321-350.

Hoskisson, R, R. Johnson, and D. Moesel, 1994, Corporate divestiture intensity in restructuring firms: Effects of governance, strategy and performance, Academy of Management Journal, 3, 1207-1251.

Jensen, Michael C., 1986, Agency cost of free cash flow, corporate finance, and takeovers, American Economic Review, 76, 323-329.

Jensen, Michael C., 1989, Eclipse of the public corporation, Harvard Business Review, 67, 61-75. 
Jensen, Michael C., and William Meckling, 1976, Theory of the firm: Managerial behavior, agency costs, and capital structure, Journal of Financial Economics, 3, 305-360.

Johnson, Simon, Peter Boone, Alasdair Breach, and Eric Friedman, 2000, Corporate governance in the Asian financial crisis, Journal of Financial Economics 58 (1-2), p. 141.

Karpoff, J., 2001, The impact of shareholder activism on target companies: A survey of empirical findings, Working Paper, University of Washington

La Porta, Rafael, Florencio Lopez-de-Silanes, Andrei Shleifer, and Robert W. Vishny, 1997, Legal determinants of external finance, Journal of Finance, 52, 1131-1150. 26.

La Porta, Rafael, Florencio Lopez-de-Silanes, Andrei Shleifer, and Robert W. Vishny, 1998, Law and finance, Journal of Political Economy, 106, 1113-1155.

La Porta, Rafael, Florencio Lopez-de-Silanes, and Andrei Shleifer, 1999, Corporate ownership around the world, Journal of Finance, 54, 471-518.

La Porta, Rafael, Florencio Lopez-de-Silanes, Andrei Shleifer, and Robert W. Vishny, 2000, Agency problems and dividend policies around the world, Journal of Finance, 55(1), 1-33.

Lang, Harry H.P., Eli Oflek, and Rene M. Stulz, 1996, Leverage, investment, and firm growth, Journal of Financial Economics, 40, 3-29.

Lemmon, Michael, and Karl V. Lins, 2003, Ownership structure, corporate governance, and firm value: Evidence from the East Asian financial crisis, Journal of Finance, 58(4), 1445-1469.

Lins, Karl V., 2003, Equity ownership and firm value in emerging markets, Journal of Financial and Quantitative Analysis, 38, 159-184.

Maug, E., 1998, Large shareholders as monitors: Is there a trade-off between liquidity and control?, Journal of Finance, 53, 65-92.

Miller, Darius, and J.J. Puthenpurackal, 2002, The costs, wealth effects and determination of international capital raising: Evidence from public yankee bonds, Journal of Financial Intermediation, 11, 455-485.

Palia, D., and Abraham Ravid, 2002, The role of founders in large companies: Entrenchment or valuable human capital?, Working Paper, Rutgers University.

Perez-Gonzalez, F., 2001, Does inherited control hurt firm performance?, Working Paper, Columbia University.

Rajan, R., and L. Zingales, 1998, Financial dependence and growth, American Economic Review, 88, 559-587. 
Roe, M., 1990, Political and legal restraints on ownership and control of public companies, Journal of Financial Economics, 27, 7-42.

Shleifer, Andrei, and Robert W. Vishny, 1986, Large shareholders and corporate control, Journal of Political Economy, 94, 461-488.

Shleifer, Andrei, and Robert W. Vishny, 1997, A survey of corporate governance, Journal of Finance, 52(2), 737-783.

Stiglitz, J., 1985, Credit markets and the control of capital, Journal of Money, Credit and Banking, 17, 133-152.

Stulz, R., 1999, Globalization of equity markets and the cost of capital, Journal of Applied Corporate Finance, 12, 8-25.

Stulz, Rene, 2005, The Limits of Financial Globalization, Journal of Finance, 60(4), 1595-1638.

Titman, Sheridan, and Roberto Wessels, 1988, The determinants of capital structure choice, Journal of Finance, 43, 1-19.

Tufano, P., 1996, Who manages risk? An empirical examination of risk management practices in the gold mining industry, Journal of Finance, 51, 1097-1137.

Villalonga, Belen and Amit Raphael, 2006, How do family ownership, control, and management affect firm value?, Journal of Financial Economics, 80, 385-418.

Wahal, S., 1996, Public pension fund activism and firm performance, Journal of Financial and Quantitative Analysis, 31, 1-23.

Weinstein, David and Yishay Yafeh, 1998, On the costs of a bank-centered financial system, Journal of Finance, 53(2), 635-672. 
Table 1. Classification of Bond Issues

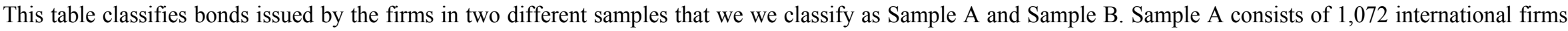

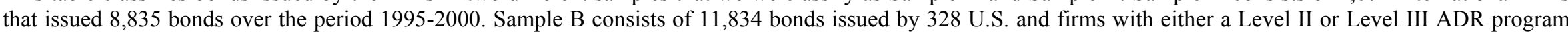

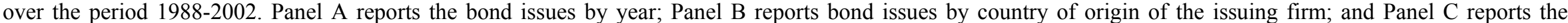
currency of issue.

Panel A: Number of bonds by year

\begin{tabular}{cccccc}
\hline Issue Year & $\begin{array}{c}\text { Number of Bonds } \\
\text { in Sample A }\end{array}$ & $\begin{array}{c}\text { Number of Bonds } \\
\text { in Sample B }\end{array}$ & $\begin{array}{c}\text { Issue Year } \\
\text { Number of Bonds } \\
\text { in Sample A }\end{array}$ & $\begin{array}{c}\text { Number of Bonds } \\
\text { in Sample B }\end{array}$ \\
\hline 1988 & - & 158 & 1995 & 832 & 794 \\
1989 & - & 212 & 1996 & 1,530 & 1,183 \\
1990 & - & 221 & 1997 & 1,408 & 1,498 \\
1991 & - & 544 & 1998 & 1,940 & 1,550 \\
1992 & - & 391 & 1999 & 1,734 & 1,228 \\
1993 & - & 505 & 2000 & 1,391 & 1,094 \\
1994 & - & 549 & 2001 & - & 1,019 \\
\end{tabular}

Panel B: Number of bonds by country of origin

\begin{tabular}{|c|c|c|c|c|c|}
\hline Country of Issuer & $\begin{array}{c}\text { Number of Bonds } \\
\text { in Sample A }\end{array}$ & $\begin{array}{c}\text { Number of Bonds } \\
\text { In Sample B }\end{array}$ & Country of Issuer & $\begin{array}{c}\text { Number of Bonds } \\
\text { in Sample A }\end{array}$ & $\begin{array}{c}\text { Number of Bonds } \\
\text { in Sample B }\end{array}$ \\
\hline Argentina & - & 41 & Mexico & - & 29 \\
\hline Australia & - & 42 & Netherlands & 155 & 59 \\
\hline Austria & 92 & - & New Zealand & - & 1 \\
\hline Belgium & 21 & - & Norway & 83 & 17 \\
\hline Brazil & - & 12 & Peru & - & - \\
\hline Canada & - & 37 & Philippines & 18 & 10 \\
\hline Finland & 11 & - & Portugal & 17 & 8 \\
\hline Chile & - & 34 & Singapore & 46 & - \\
\hline Denmark & - & 2 & South Africa & - & 2 \\
\hline Finland & 18 & 11 & South Korea & 80 & 31 \\
\hline France & 461 & 118 & Spain & 55 & 21 \\
\hline Germany & 725 & 120 & Sweden & 125 & 55 \\
\hline Greece & - & 3 & Switzerland & 179 & 10 \\
\hline Indonesia & 27 & 1 & Taiwan & 413 & - \\
\hline Ireland & 11 & 2 & Thailand & 65 & - \\
\hline Italy & 71 & 92 & United Kingdom & 886 & 289 \\
\hline Japan & 2,528 & 555 & United States & 2,695 & 10,228 \\
\hline Malaysia & 53 & - & Venezuela & - & 4 \\
\hline
\end{tabular}


Panel C. Number of bonds by currency

\begin{tabular}{|c|c|c|c|c|c|}
\hline Currency of the Issue & $\begin{array}{c}\text { Number of Bonds } \\
\text { in Sample A }\end{array}$ & $\begin{array}{c}\text { Number of Bonds } \\
\text { in Sample B }\end{array}$ & Currency of the Issue & $\begin{array}{c}\text { Number of Bonds } \\
\text { in Sample A }\end{array}$ & $\begin{array}{c}\text { Number of Bonds } \\
\text { in Sample B }\end{array}$ \\
\hline Austrian Schilling & 8 & - & Italian Lira & 31 & 49 \\
\hline Australian Dollar & - & 43 & Japanese Yen & 2,838 & 600 \\
\hline Brazilian Real & - & 3 & Malaysian Ringgit & 35 & - \\
\hline British Pound & 387 & 250 & Mexican Peso & - & 19 \\
\hline Belgium Franc & 6 & - & Norwegian Krone & 23 & 12 \\
\hline Canadian Dollar & - & 113 & New Zealand Dollar & - & 23 \\
\hline Czech Koruna & 14 & 15 & Philippines Peso & 8 & - \\
\hline Dutch Florin & 24 & 21 & Portuguese Escudo & 5 & 14 \\
\hline Deutsche Mark & 489 & 90 & Spanish Peseta & 11 & - \\
\hline Greek Drahma & 2 & 2 & Swiss Franc & 308 & 195 \\
\hline Euro & 469 & 386 & Singapore Dollar & 59 & 20 \\
\hline Finnish Markka & 8 & - & Swedish Krona & 39 & 15 \\
\hline French Franc & 171 & 78 & Taiwan Dollar & 402 & - \\
\hline Hong Kong Dollar & 98 & 29 & Thai Baht & 61 & - \\
\hline Indonesian Rupiah & 24 & - & U.S. Dollar & 3,310 & 9,857 \\
\hline Irish Pound & 5 & - & & & \\
\hline
\end{tabular}


Table 2. Descriptive Statistics of Bond Issues and Issuing Firms

This table classifies the bonds issued by the firms in Sample A and Sample B. Sample A consists of 1,072 international firms that issued 8,835 bonds over the period 1995-2000. Sample B consists of 11,834 bonds issued by 328 U.S. and firms with either a Level II or Level III ADR program over the period 1988-2002. The variables are described in Table 3.

Panel A. Bond-level statistics for Sample A

\begin{tabular}{lrrrrr}
\hline \multicolumn{1}{c}{ Variable } & \multicolumn{1}{c}{ Mean } & Median & \multicolumn{1}{c}{ St. Dev } & \multicolumn{1}{c}{ Min } & \multicolumn{1}{c}{ Max } \\
\hline Yield Spread (\%) & 1.75 & 1.64 & 1.71 & -2.86 & 7.82 \\
Yield-to-Maturity (\%) & 4.97 & 5.25 & 3.11 & 0.32 & 39.95 \\
Coupon (\%) & 5.09 & 5.69 & 2.74 & 0.50 & 22.30 \\
Risk free Rate (\%) & 3.39 & 4.50 & 2.50 & 0.21 & 17.42 \\
Maturity (years) & 7.47 & 5.08 & 7.98 & 1 & 32.42 \\
Principal Amount (mm\$) & 150.05 & 89.2 & 168.77 & 3 & 986.9 \\
\hline
\end{tabular}

Panel B. Bond-level statistics for Sample B

\begin{tabular}{lrrrrr}
\hline \multicolumn{1}{c}{ Variable } & Mean & Median & \multicolumn{1}{c}{ St. Dev } & \multicolumn{1}{c}{ Min } & \multicolumn{1}{c}{ Max } \\
\hline Yield Spread (\%) & 1.34 & 1.05 & 1.60 & -2.93 & 7.52 \\
Yield-to-Maturity (\%) & 6.57 & 6.58 & 2.25 & 0.52 & 39.95 \\
Coupon (\%) & 6.88 & 6.70 & 2.05 & 0.6 & 18.00 \\
Risk free Rate (\%) & 4.64 & 5.08 & 1.89 & 0.21 & 17.37 \\
Maturity (years) & 6.44 & 4.06 & 7.18 & 1 & 50.79 \\
Rating & 2.63 & 3.00 & 0.94 & 1.00 & 6.00 \\
Principal Amount (mm\$) & 139.10 & 86.5 & 159.8 & 3 & 996.5 \\
\hline
\end{tabular}


Panel C. Firm-level and external governance statistics

\begin{tabular}{|c|c|c|c|c|c|c|}
\hline \multirow[b]{2}{*}{ Variable } & \multicolumn{3}{|c|}{ Sample A } & \multicolumn{3}{|c|}{ Sample B } \\
\hline & Mean & Median & Std. Dev & Mean & Median & Std. Dev \\
\hline \multicolumn{7}{|l|}{ Firm Characteristics } \\
\hline \multicolumn{7}{|l|}{ Family-owned (Non-Family owned) } \\
\hline \multirow[t]{2}{*}{ Long Term Debt Ratio (\%) } & 25.89 & 25.37 & 16.46 & 28.50 & 26.61 & 14.10 \\
\hline & $(23.81)$ & $(20.61)$ & $(16.08)$ & $(23.9)$ & $(23.01)$ & $(13.82)$ \\
\hline \multirow{2}{*}{ Total Assets (mm\$) } & 958 & 283 & 6,189 & 13,635 & 2,279 & 34,130 \\
\hline & $(1,890)$ & $(691)$ & $(6,641)$ & $(32,773)$ & $(11,542)$ & $(59,158)$ \\
\hline \multirow[t]{2}{*}{ Operating Income / Total Assets } & 0.067 & 0.445 & 0.0766 & 0.117 & 0.127 & 0.067 \\
\hline & $(0.063)$ & $(0.398)$ & $(0.070)$ & $(0.105)$ & $(0.107)$ & $(0.064)$ \\
\hline \multirow[t]{2}{*}{ Market to Book Ratio } & 3.154 & 2.355 & 3.0826 & 3.037 & 2.388 & 2.377 \\
\hline & $(2.695)$ & $(1.942)$ & $(2.194)$ & $(2.355)$ & $(1.901)$ & $(1.937)$ \\
\hline \multirow[t]{2}{*}{ Dividend Dummy } & 0.674 & 1.000 & 0.481 & 0.743 & 1.000 & 0.443 \\
\hline & $(0.821)$ & $(1.000)$ & $(0.360)$ & $(0.864)$ & $(1.000)$ & $(0.343)$ \\
\hline \multicolumn{7}{|l|}{ Ownership and External Governance } \\
\hline \multicolumn{7}{|l|}{ Family-owned (Non-Family owned) } \\
\hline \multirow[t]{2}{*}{ Family Ownership (\%) } & 42.387 & 40.833 & 28.411 & 27.168 & 23.000 & 24.810 \\
\hline & $(-)$ & $(-)$ & $(-)$ & $(-)$ & $(-)$ & $(-)$ \\
\hline \multirow[t]{2}{*}{ Family in Management } & 0.649 & 1.00 & 0.478 & 0.543 & 1.000 & 0.505 \\
\hline & $(-)$ & $(-)$ & $(-)$ & $(-)$ & $(-)$ & $(-)$ \\
\hline \multirow[t]{2}{*}{ Non-family Blockholder (\%) } & - & - & - & 12.196 & 3.118 & 21.792 \\
\hline & & & & $(18.361)$ & $(12.315)$ & $(19.481)$ \\
\hline \multirow[t]{2}{*}{ Non-family Inside Blockholder (\%) } & - & - & - & 2.516 & 0.000 & 10.509 \\
\hline & & & & $(6.228)$ & $(2.815)$ & $(15.620)$ \\
\hline \multirow[t]{2}{*}{ Legality Index } & 18.484 & 19.668 & 2.734 & 18.451 & 19.850 & 3.489 \\
\hline & $(20.208)$ & $(20.36)$ & $(1.045)$ & (20.179) & $(20.850)$ & $(2.052)$ \\
\hline \multirow[t]{2}{*}{ Creditors' Rights Index } & 1.223 & 1.000 & 0.5502 & 1.289 & 1.000 & 0.514 \\
\hline & $(1.864)$ & $(1.000)$ & $(0.738)$ & $(1.946)$ & $(1.000)$ & $(1.083)$ \\
\hline \multirow[t]{2}{*}{ GDP per Capita (\$) } & 15,793 & 11,425 & 10,128 & 20,633 & 26,211 & 10,341 \\
\hline & $(25,944)$ & $(31,490)$ & $(7,056)$ & $(26,486)$ & $(27,334)$ & $(7,364)$ \\
\hline
\end{tabular}


Table 3. Variable Definitions

\begin{tabular}{|c|c|}
\hline Name of the Variable & Definition \\
\hline \multicolumn{2}{|l|}{ Bond-Level Characteristics } \\
\hline Yield Spread & $\begin{array}{l}\text { Offer yield to maturity of the issue minus the three-month } \\
\text { Government risk free rate. }\end{array}$ \\
\hline Risk-free Rate & $\begin{array}{l}\text { The yield on the 3-Month Government (Treasury) Bonds } \\
\text { for the currency in which the bond is issued. We also use } \\
\text { the yield on 10-Year Government Bonds for issues made in } \\
21 \text { currencies. }\end{array}$ \\
\hline Bond Rating & $\begin{array}{l}\text { Defined in three different ways: (a) the ordinal Moody's } \\
\text { rating }(\mathrm{Aa}=1, \mathrm{Aa}=2, \mathrm{~A}=3, \mathrm{Baa}=4, \mathrm{Ba}=5, \mathrm{~B} \text { or below }=6 \text { ), } \\
\text { (b) the } \log \text { of the Ratings, and (c) the squared term of the } \\
\text { Ratings. }\end{array}$ \\
\hline Log Maturity & Natural logarithm of the issue maturity. \\
\hline Log Proceeds & Natural logarithm of the dollar proceeds of bond issue. \\
\hline \multicolumn{2}{|l|}{ Firm-Level Characteristics } \\
\hline Long-Term Debt Ratio & Long-term debt divided by total assets. \\
\hline Log Total Assets & Natural logarithm of total assets. \\
\hline Operating Income / Total Assets & $\begin{array}{l}\text { Operating income before depreciation divided by total } \\
\text { assets. }\end{array}$ \\
\hline Market-to-Book Ratio & Market value of equity divided by common equity. \\
\hline \multicolumn{2}{|l|}{ Firm Ownership Measures } \\
\hline Family Ownership & Percentage ownership of the founding family in the firm. \\
\hline Family Dummy & $\begin{array}{l}\text { Equals one if the founding family owns shares in the firm, } \\
\text { zero otherwise. }\end{array}$ \\
\hline Family in Management & $\begin{array}{l}\text { A dummy variable that equals to one if family is in the } \\
\text { active management of the firm, zero otherwise. }\end{array}$ \\
\hline Family Wedge & $\begin{array}{l}\text { A dummy variable that equals to one if there is a difference } \\
\text { between the family's cash flow rights and its voting rights. }\end{array}$ \\
\hline Non-family Blockholder & $\begin{array}{l}\text { Percentage ownership of a firm or person that owns at least } \\
5 \% \text { of the outstanding shares and is not part of the founding } \\
\text { family. We also use a dummy variable. }\end{array}$ \\
\hline Non-family Inside Blockholder & $\begin{array}{l}\text { Percentage ownership of a firm or person that owns at least } \\
5 \% \text { of the outstanding shares, is not part of the founding } \\
\text { family and is in active management. We also use a dummy } \\
\text { variable. }\end{array}$ \\
\hline
\end{tabular}


Percentage ownership of a firm or person that owns at least $5 \%$ of the outstanding shares, is not part of the founding family and is not in active management. We also use a dummy variable.

\section{Country-Level Governance Measures}

Legal Environment (Legality)

Creditor Rights Index

Legal Environment is derived from a principal components analysis of the covariance matrix from the efficiency of the judiciary system, rule of law, corruption, risk of expropriation, and the risk of contract repudiation. Obtained from Berkowitz, Pistor, and Richard (1999).

Creditor Rights Index is an aggregate measure of creditor rights. It measures how well creditor rights are protected under bankruptcy and reorganization laws. This Index is obtained from LLSV (1998). Higher values refer to stronger creditor protection.

\section{Country-Level Characteristics}

Ratio of Stock Market Capitalization to GDP

The size of the stock market relative to the size of the country's economy and calculated annually. 


\section{Table 4. Family Presence and Cost of Debt in Different Investor Protection Environments}

This table provides the estimates of a cross-sectional regression model using one bond issue for each firm included in Sample A consisting of 1,072 international firms that issued 8,835 bonds over the period 1995-2000. The results shown in columns 6 and 7 are for a sub-sample of bonds issued and included in Sample A for which we are able to obtain information about bond ratings issued by credit rating agencies. The results in column $1,2,5,6$ and 7 use a random bond issue for each firm. The results in column 3 use the first bond issue of each firm while column 4 shows the results using the last bond issue of each firm. The dependent variable is the yield spread of the bond issue defined as the offer yield-to-maturity minus the yield on the 3-month yield Treasury bond. We define the independent variables in Table 3. Standard errors are corrected for serial correlation and heteroscedasticity. The t-statistics appear in parentheses below parameter estimates. $* * *, * *$, and $*$ indicate significance at $1 \%, 5 \%$, and $10 \%$ level respectively.

\begin{tabular}{|c|c|c|c|c|c|c|c|}
\hline & 1 & 2 & 3 & 4 & 5 & 6 & 7 \\
\hline Family Presence (Dummy) & $\begin{array}{c}3.1352 * * \\
(2.02)\end{array}$ & $\begin{array}{c}0.7064^{*} \\
(1.92)\end{array}$ & $\begin{array}{l}3.756^{*} \\
(1.89)\end{array}$ & & & & $\begin{array}{c}0.6591 * \\
(1.91)\end{array}$ \\
\hline Family Presence ( $\%$ Ownership) & & & & $\begin{array}{l}0.0161 * * \\
(2.08)\end{array}$ & $\begin{array}{l}0.0781 * * \\
(1.95)\end{array}$ & $\begin{array}{c}0.0155^{*} \\
(1.85)\end{array}$ & \\
\hline Family Presence x Legality & $\begin{array}{c}-0.1568 * * \\
(-1.99)\end{array}$ & & $\begin{array}{c}-0.1890^{*} \\
(-1.88)\end{array}$ & & $\begin{array}{c}-0.0036^{* *} \\
(-2.05)\end{array}$ & & \\
\hline $\begin{array}{l}\text { Family Presence x } \\
\text { Creditors' Rights }\end{array}$ & & $\begin{array}{c}-0.3915^{*} \\
(-1.91)\end{array}$ & & $\begin{array}{c}-0.0078 * * \\
(-2.12)\end{array}$ & & $\begin{array}{c}-0.0071 * \\
(-1.92)\end{array}$ & $\begin{array}{c}-0.3208 * * \\
(-1.98)\end{array}$ \\
\hline Legality & $\begin{array}{c}-0.1476 \\
(-1.48)\end{array}$ & $\begin{array}{c}-0.2966 * * * \\
(-3.76)\end{array}$ & $\begin{array}{c}-0.2602 * * \\
(-2.28)\end{array}$ & $\begin{array}{l}-0.1203 \\
(-2.21)\end{array}$ & $\begin{array}{l}-0.0931 \\
(-1.84)\end{array}$ & $\begin{array}{c}0.0383 \\
(0.40)\end{array}$ & $\begin{array}{c}-0.20003 * * * \\
(-4.60)\end{array}$ \\
\hline Creditors' Rights & $\begin{array}{c}0.1242 \\
(0.40)\end{array}$ & $\begin{array}{c}-0.6574^{*} \\
(-1.83)\end{array}$ & $\begin{array}{c}0.0716 \\
(0.21)\end{array}$ & $\begin{array}{c}0.0916 \\
(0.61)\end{array}$ & $\begin{array}{c}-0.1010 \\
(-0.99)\end{array}$ & $\begin{array}{c}0.0157 \\
(0.06)\end{array}$ & $\begin{array}{c}-0.8836^{*} \\
(-1.91)\end{array}$ \\
\hline Stock Market Capitalization & $\begin{array}{c}-5.0029 \\
(-0.90)\end{array}$ & $\begin{array}{c}-6.0049 * \\
(-1.69)\end{array}$ & $\begin{array}{c}-6.0064 * \\
(-1.71)\end{array}$ & $\begin{array}{c}-5.0009 \\
(-0.38)\end{array}$ & $\begin{array}{c}-5.0032 \\
(-1.28)\end{array}$ & $\begin{array}{c}-5.0042 \\
(-0.92)\end{array}$ & $\begin{array}{c}-5.0014 \\
(-1.08)\end{array}$ \\
\hline Risk Free Rate & $\begin{array}{c}-0.3102 * * * \\
(-4.41)\end{array}$ & $\begin{array}{c}-0.3061 * * * \\
(-4.33)\end{array}$ & $\begin{array}{c}-0.3486 * * * \\
(-4.30)\end{array}$ & $\begin{array}{c}-0.2521 * * \\
(-2.06)\end{array}$ & $\begin{array}{l}-0.2235 \\
(-2.18)\end{array}$ & $\begin{array}{c}-0.1248 * * * \\
(-3.13)\end{array}$ & $\begin{array}{c}-0.1693 * * * \\
(-4.32)\end{array}$ \\
\hline Bond Rating & & & & & & $\begin{array}{l}0.1292 * * * \\
(9.29)\end{array}$ & $\begin{array}{c}0.1191 * * * \\
(9.18)\end{array}$ \\
\hline Callable Bond Issue & & & & & & $\begin{array}{c}-0.0125 \\
(-0.06)\end{array}$ & $\begin{array}{c}0.0623 \\
(0.30)\end{array}$ \\
\hline Subordinated Bond Issue & & & & & & $\begin{array}{c}0.5520 * \\
(1.85)\end{array}$ & $\begin{array}{c}0.6617 * * \\
(-2.01)\end{array}$ \\
\hline Log Maturity & $\begin{array}{c}0.5281 * * * \\
(6.89)\end{array}$ & $\begin{array}{c}0.5287 * * * \\
(6.92)\end{array}$ & $\begin{array}{c}0.3339 * * * \\
(3.78)\end{array}$ & $\begin{array}{c}0.3595 * * * \\
(2.86)\end{array}$ & $\begin{array}{c}0.4481 * * * \\
(4.39)\end{array}$ & $\begin{array}{c}0.4336^{* * * *} \\
(5.03)\end{array}$ & $\begin{array}{c}0.4718 * * * \\
\quad(5.70)\end{array}$ \\
\hline Log Principal & $\begin{array}{c}0.0535 \\
(0.94)\end{array}$ & $\begin{array}{c}0.0487 \\
(0.85)\end{array}$ & $\begin{array}{c}0.0436 \\
(0.83)\end{array}$ & $\begin{array}{c}0.1987 * * * \\
(3.01)\end{array}$ & $\begin{array}{c}0.0123 \\
(0.16)\end{array}$ & $\begin{array}{c}0.0845^{*} \\
(1.68)\end{array}$ & $\begin{array}{c}0.0960^{*} \\
(1.71)\end{array}$ \\
\hline
\end{tabular}




\begin{tabular}{|c|c|c|c|c|c|c|c|}
\hline Long Term Debt Ratio & $\begin{array}{c}0.9251 * * \\
(2.28)\end{array}$ & $\begin{array}{c}0.9713 * * \\
(2.37)\end{array}$ & $\begin{array}{c}2.0328 * * * \\
(3.15)\end{array}$ & $\begin{array}{l}1.6853 * * * \\
(2.97)\end{array}$ & $\begin{array}{l}1.5220 * * * \\
(2.75)\end{array}$ & $\begin{array}{c}1.1481 * * \\
(1.96)\end{array}$ & $\begin{array}{c}0.8409 * \\
(1.70)\end{array}$ \\
\hline Log of Total Assets & -0.0255 & -0.0272 & -0.0718 & $-0.1198 * *$ & -0.0338 & 0.0100 & 0.0169 \\
\hline & $(-0.74)$ & $(-0.79)$ & $(-1.59)$ & $(-2.56)$ & $(-0.83)$ & $(0.27)$ & $(0.52)$ \\
\hline Operating Income / Total Assets & $-2.0457 * *$ & $-2.0699 * *$ & 0.9038 & -2.0560 & $-1.9986^{*}$ & $-1.6514^{*}$ & $-1.4152 *$ \\
\hline & $(-2.00)$ & $(-1.99)$ & $(0.64)$ & $(-1.48)$ & $(-1.84)$ & $(-1.87)$ & $(-1.72)$ \\
\hline Market-to-Book Ratio & $0.0229 * *$ & $0.0223 * *$ & $0.0034 *$ & 0.0002 & $0.0217 * *$ & 0.0141 & $0.0192 *$ \\
\hline & (2.19) & $(2.03)$ & $(1.65)$ & $(1.19)$ & $(1.99)$ & $(1.02)$ & $(1.75)$ \\
\hline Intercept & $4.4362 * * *$ & $6.1454 * * *$ & $7.0411 * * *$ & 2.1749 & $2.9216^{* *}$ & 0.4411 & $4.6903 * * *$ \\
\hline & $(2.61)$ & $(4.22)$ & $(3.67)$ & $(1.05)$ & $(2.23)$ & $(0.24)$ & $(3.73)$ \\
\hline Time Dummies & YES & YES & YES & YES & YES & YES & YES \\
\hline Industry Dummies & YES & YES & YES & YES & YES & YES & YES \\
\hline Country Dummies & YES & YES & YES & YES & YES & YES & YES \\
\hline Observation & Random & Random & First & Last & Random & Random & Random \\
\hline Number of Observations & 1,072 & 1,072 & 1,072 & 1,072 & 1,072 & 659 & 659 \\
\hline Adjusted $\mathrm{R}^{2}$ & 0.3088 & 0.3068 & 0.2824 & 0.1913 & 0.3195 & 0.4228 & 0.3617 \\
\hline
\end{tabular}




\section{Table 5. Family Presence and Cost of Debt in Different Investor Protection Environments}

This table provides the estimates of a linear regression model using various fixed effects for international bonds issues. The results reported in columns $1-6$ are obtained using Sample A consisting of 1,072 international firms that issued 8,835 bonds over the period 1995-2000. The results shown in column 6 are for a subsample of bonds included in Sample A for which we are able to obtain information about bond ratings issued by credit rating agencies. The results in columns 7 and 8 are obtained using Sample B consisting of 328 U.S. and international firms with either a Level II or Level III ADR that issued 11,834 bonds over the period 19882002. The dependent variable is the yield spread of the bond issue defined as the offer yield-to-maturity minus the yield on the 3 -month yield Treasury bond. We define the independent variables in Table 3. Standard errors are corrected for serial correlation and heteroscedasticity. The t-statistics appear in parentheses below parameter estimates. $* * *, * *$, and $*$ indicate significance at $1 \%, 5 \%$, and $10 \%$ level respectively.

\begin{tabular}{|c|c|c|c|c|c|c|c|c|}
\hline & 1 & 2 & 3 & 4 & 5 & 6 & 7 & 8 \\
\hline Family Presence (Dummy) & $\begin{array}{c}4.3708 * * \\
(2.49)\end{array}$ & $\begin{array}{c}4.2115 * * \\
(2.11)\end{array}$ & $\begin{array}{c}4.6546^{*} \\
(1.92)\end{array}$ & & & & & \\
\hline Family Presence (\% Ownership) & & & & $\begin{array}{c}0.0696^{*} \\
(1.82)\end{array}$ & $\begin{array}{l}0.0110^{* *} \\
(2.41)\end{array}$ & $\begin{array}{l}0.0091 * * \\
(2.08)\end{array}$ & $\begin{array}{c}0.0151^{*} \\
(1.86)\end{array}$ & $\begin{array}{c}0.0140^{*} \\
(1.94)\end{array}$ \\
\hline Family Presence x Legality & $\begin{array}{c}-0.2172 * * \\
(-2.56)\end{array}$ & $\begin{array}{c}-0.2126^{* *} \\
(-2.10)\end{array}$ & $\begin{array}{c}-0.2304^{*} \\
(-1.90)\end{array}$ & $\begin{array}{c}-0.0032 * * \\
(-2.15)\end{array}$ & & & & \\
\hline $\begin{array}{l}\text { Family Presence x } \\
\text { Creditors' Rights }\end{array}$ & & & & & $\begin{array}{c}-0.0062^{*} \\
(1.88)\end{array}$ & $\begin{array}{c}-0.0051^{*} \\
(-1.90)\end{array}$ & $\begin{array}{c}-0.0079 * \\
(-1.91)\end{array}$ & $\begin{array}{c}-0.0071^{* *} \\
(-2.01)\end{array}$ \\
\hline Stock Market Capitalization & $\begin{array}{c}-5.0018 \\
(-1.27)\end{array}$ & $\begin{array}{c}-6.6020^{*} \\
(-1.68)\end{array}$ & $\begin{array}{c}-5.1021 \\
(-1.36)\end{array}$ & $\begin{array}{c}-5.0029 \\
(-1.15)\end{array}$ & $\begin{array}{c}-5.0012 \\
(-1.06)\end{array}$ & $\begin{array}{c}-5.2043 \\
(-1.53)\end{array}$ & $\begin{array}{c}-7.0965^{*} \\
(-1.91)\end{array}$ & $\begin{array}{c}-7.0219 * \\
(-1.79)\end{array}$ \\
\hline Risk Free Rate & $\begin{array}{c}-0.1360 * * * \\
(-13.01)\end{array}$ & $\begin{array}{c}-0.1380 * * * \\
(-13.19)\end{array}$ & $\begin{array}{c}-0.1436 * * * \\
(-13.69)\end{array}$ & $\begin{array}{c}-0.1157 * * * \\
(-9.12)\end{array}$ & $\begin{array}{c}-0.1158 * * * \\
(-9.13)\end{array}$ & $\begin{array}{c}-0.2258 * * * \\
(-29.03)\end{array}$ & $\begin{array}{c}-0.2258 * * * \\
(-29.03)\end{array}$ & $\begin{array}{c}-0.2121 * * * \\
(-27.86)\end{array}$ \\
\hline Bond Rating & & & & & & $\begin{array}{c}0.0913 * * * \\
(26.69)\end{array}$ & $\begin{array}{c}0.0607 * * * \\
(16.62)\end{array}$ & $\begin{array}{c}0.0622 * * * \\
(25.19)\end{array}$ \\
\hline Callable Bond Issue & & & & & & $\begin{array}{l}0.1306^{* *} \\
(2.35)\end{array}$ & $\begin{array}{l}0.1516^{* * *} \\
(5.51)\end{array}$ & $\begin{array}{l}0.2581 * * * \\
(7.81)\end{array}$ \\
\hline Subordinated Bond Issue & & & & & & $\begin{array}{c}0.2102 * * \\
(2.06)\end{array}$ & $\begin{array}{c}0.5035 * * * \\
(7.11)\end{array}$ & $\begin{array}{c}0.3969 * * * \\
(8.95)\end{array}$ \\
\hline Log Maturity & $\begin{array}{c}0.5103 * * * \\
(25.05)\end{array}$ & $\begin{array}{c}0.5066 * * * \\
(24.87)\end{array}$ & $\begin{array}{c}0.5009 * * * \\
(24.56)\end{array}$ & $\begin{array}{c}0.4683 * * * \\
(19.09)\end{array}$ & $\begin{array}{c}0.4686 * * * \\
(19.10)\end{array}$ & $\begin{array}{l}0.4911 * * * \\
(23.68)\end{array}$ & $\begin{array}{c}0.7174 * * * \\
(-5.97)\end{array}$ & $\begin{array}{c}0.7518 * * * \\
(10.78)\end{array}$ \\
\hline Log Principal & $\begin{array}{c}-0.0384 * * * \\
(-2.84)\end{array}$ & $\begin{array}{c}-0.0373 * * \\
(-2.76)\end{array}$ & $\begin{array}{c}-0.0336 * * * \\
(-2.47)\end{array}$ & $\begin{array}{c}-0.0495 * * * \\
(-2.85)\end{array}$ & $\begin{array}{c}-0.0504 * * * \\
(-2.90)\end{array}$ & $\begin{array}{c}0.0027 \\
(0.19)\end{array}$ & $\begin{array}{c}-0.0520 * * * \\
(-5.99)\end{array}$ & $\begin{array}{c}-0.0538 * * * \\
(-6.81)\end{array}$ \\
\hline Long Term Debt Ratio & $\begin{array}{c}0.5896 * * * * \\
(4.66)\end{array}$ & $\begin{array}{c}0.5897 * * * \\
(4.66)\end{array}$ & $\begin{array}{c}0.4617 * * * \\
(3.56)\end{array}$ & $\begin{array}{c}0.4058 * * \\
(2.29)\end{array}$ & $\begin{array}{c}0.4043 * * \\
(2.28)\end{array}$ & $\begin{array}{c}0.3734^{*} \\
(1.87)\end{array}$ & $\begin{array}{c}0.8552 \\
(1.59)\end{array}$ & $\begin{array}{c}0.1653 \\
(1.43)\end{array}$ \\
\hline Log of Total Assets & $\begin{array}{c}-0.0495 * * * \\
(-4.87)\end{array}$ & $\begin{array}{c}-0.0496 * * * \\
(-4.88)\end{array}$ & $\begin{array}{c}-0.0345^{* * * *} \\
(-3.32)\end{array}$ & $\begin{array}{c}-0.0741 * * * \\
(-4.65)\end{array}$ & $\begin{array}{c}-0.0753 * * * \\
(-4.73)\end{array}$ & $\begin{array}{c}-0.0243^{*} \\
(-1.68)\end{array}$ & $\begin{array}{c}-0.0467 \\
(-0.93)\end{array}$ & $\begin{array}{l}0.0091 \\
(0.70)\end{array}$ \\
\hline Operating Income / Total Assets & $-2.3540 * * *$ & $-2.3543 * * *$ & $-2.2825 * * *$ & $-2.1321 * * *$ & $-2.1639 * * *$ & $-1.2634 * * *$ & $-2.2298 * * *$ & -0.2140 \\
\hline
\end{tabular}




\begin{tabular}{|c|c|c|c|c|c|c|c|c|}
\hline & $(-7.54)$ & $(-7.55)$ & $(-7.16)$ & $(-5.46)$ & $(-5.54)$ & $(-3.86)$ & $(-3.94)$ & $(-0.85)$ \\
\hline Market-to-Book Ratio & 0.0011 & 0.0011 & 0.0008 & 0.0008 & 0.0008 & 0.0019 & $0.0243 * * *$ & $0.0160 * * *$ \\
\hline & $(1.17)$ & $(1.17)$ & $(0.94)$ & $(0.79)$ & $(0.80)$ & $(1.35)$ & $(2.98)$ & $(3.08)$ \\
\hline Intercept & $\begin{array}{c}7.5900 * * * \\
(6.34)\end{array}$ & $\begin{array}{c}2.2776^{* * *} \\
(2.21)\end{array}$ & $\begin{array}{c}4.7276 \\
(1.28)\end{array}$ & $\begin{array}{c}7.9276^{* *} \\
(2.00)\end{array}$ & $\begin{array}{c}7.3451 * \\
(1.84)\end{array}$ & $\begin{array}{c}3.6463^{*} \\
(1.83)\end{array}$ & $\begin{array}{c}-11.6981 * * \\
(-2.56)\end{array}$ & $\begin{array}{c}10.9194 * * * \\
(5.14)\end{array}$ \\
\hline Time Dummies & YES & YES & YES & YES & YES & YES & YES & YES \\
\hline Industry Dummies & YES & YES & YES & YES & YES & YES & Dropped & YES \\
\hline Country Dummies & YES & YES & YES & YES & YES & YES & Dropped & YES \\
\hline Fixed Effects & Industry & Country & $\begin{array}{l}\text { Country and } \\
\text { Industry }\end{array}$ & $\begin{array}{l}\text { Country and } \\
\text { Industry }\end{array}$ & $\begin{array}{l}\text { Country and } \\
\text { Industry }\end{array}$ & $\begin{array}{l}\text { Country and } \\
\text { Industry }\end{array}$ & Firm & $\begin{array}{l}\text { Country and } \\
\text { Industry }\end{array}$ \\
\hline Number of Observations & 8,835 & 8,835 & 8,835 & 8,835 & 8,835 & 6,015 & 11,834 & 11,834 \\
\hline Adjusted $\mathrm{R}^{2}$ & 0.2046 & 0.1722 & 0.0785 & 0.0718 & 0.0673 & 0.2848 & 0.1263 & 0.4080 \\
\hline
\end{tabular}




\section{Table 6. Family Presence and Cost of Debt in Different Investor Protection Environments}

This table provides the estimates of a linear regression model using various fixed effects for international bonds issues. The results reported in columns $1-6$ are obtained using Sample A consisting of 1,072 international firms that issued 8,835 bonds over the period 1995-2000. The results shown in column 6 are for a subsample of bonds included in Sample A for which we are able to obtain information about bond ratings issued by credit rating agencies. The results in columns 7 and 8 are obtained using Sample B consisting of 328 U.S. and international firms with either a Level II or Level III ADR that issued 11,834 bonds over the period 19882002. The dependent variable is the yield spread of the bond issue defined as the offer yield-to-maturity minus the yield on the 3 -month yield Treasury bond. We define the independent variables in Table 3. Standard errors are corrected for serial correlation and heteroscedasticity. The t-statistics appear in parentheses below parameter estimates. $* * *, * *$, and $*$ indicate significance at $1 \%, 5 \%$, and $10 \%$ level respectively.

\begin{tabular}{|c|c|c|c|c|c|c|c|c|}
\hline & 1 & 2 & 3 & 4 & 5 & 6 & 7 & 8 \\
\hline Family Presence (Dummy) & $\begin{array}{l}3.8519 * * \\
(2.08)\end{array}$ & $\begin{array}{c}1.1845^{*} \\
(1.85)\end{array}$ & & $\begin{array}{l}4.7361^{* *} \\
(2.05)\end{array}$ & $\begin{array}{l}6.1637^{* *} \\
(2.58)\end{array}$ & $\begin{array}{c}4.8595^{*} \\
(1.82)\end{array}$ & & $\begin{array}{l}1.55379 * * \\
(2.08)\end{array}$ \\
\hline Family Presence (\% Ownership) & & & $\begin{array}{c}0.0149 * \\
(1.89)\end{array}$ & & & & $\begin{array}{c}0.0975^{*} \\
(1.86)\end{array}$ & \\
\hline Family Presence x Legality & $\begin{array}{c}-0.1907 * * \\
(-2.10)\end{array}$ & & & $\begin{array}{c}-0.2333 * \\
(-1.91)\end{array}$ & $\begin{array}{c}-0.3119 * * \\
(-2.08)\end{array}$ & $\begin{array}{c}-0.2607 * \\
(1.85)\end{array}$ & $\begin{array}{c}-0.0053 * * \\
(-2.00)\end{array}$ & \\
\hline $\begin{array}{l}\text { Family Presence x } \\
\text { Creditors' Rights }\end{array}$ & & $\begin{array}{c}-0.5910^{*} \\
(-1.88)\end{array}$ & $\begin{array}{c}-0.0075^{* *} \\
(-2.04)\end{array}$ & & & & & $\begin{array}{c}-0.7014^{*} \\
(-1.83)\end{array}$ \\
\hline Stock Market Capitalization & $\begin{array}{c}-5.0070 \\
(-1.15)\end{array}$ & $\begin{array}{c}-5.0084 \\
(-1.49)\end{array}$ & $\begin{array}{c}-5.0062 \\
(-1.05)\end{array}$ & $\begin{array}{c}-5.0104 \\
(-1.19)\end{array}$ & $\begin{array}{c}-5.0004 \\
(-1.47)\end{array}$ & $\begin{array}{c}-7.0103 * \\
(-1.88)\end{array}$ & $\begin{array}{c}-7.0092 * \\
(-1.72)\end{array}$ & $\begin{array}{c}-6.9051^{*} \\
(-1.84)\end{array}$ \\
\hline Risk Free Rate & $\begin{array}{c}-0.1408 * * * \\
(-13.46)\end{array}$ & $\begin{array}{c}-0.2564 * * * \\
(-20.09)\end{array}$ & $\begin{array}{c}-0.2102 * * * \\
(-11.64)\end{array}$ & $\begin{array}{c}-0.1364 * * * \\
(-13.07)\end{array}$ & $\begin{array}{c}-0.1682 * * * \\
(-4.88)\end{array}$ & $\begin{array}{c}-0.2120 * * * \\
(-27.85)\end{array}$ & $\begin{array}{c}-0.2118 * * * \\
(-27.78)\end{array}$ & $\begin{array}{c}-0.3730 * * * \\
(23.46)\end{array}$ \\
\hline Bond Rating & & & & & & $\begin{array}{l}0.0628 * * * \\
(25.44)\end{array}$ & $\begin{array}{l}0.0622 * * * \\
(25.11)\end{array}$ & $\begin{array}{l}0.0625 * * * \\
(25.64)\end{array}$ \\
\hline Callable Bond Issue & & & & & & $\begin{array}{l}0.2567 * * \\
(7.79)\end{array}$ & $\begin{array}{l}0.2565 * * * \\
(7.71)\end{array}$ & $\begin{array}{l}0.2141 * * * \\
(6.63)\end{array}$ \\
\hline Subordinated Bond Issue & & & & & & $\begin{array}{l}0.3955^{* *} \\
(5.94)\end{array}$ & $\begin{array}{l}0.3952 * * * \\
(5.93)\end{array}$ & $\begin{array}{l}0.3507 * * * \\
\quad(5.40)\end{array}$ \\
\hline Log Maturity & $\begin{array}{l}0.5044 * * * \\
(24.85)\end{array}$ & $\begin{array}{l}0.5352 * * * \\
(20.68)\end{array}$ & $\begin{array}{l}0.4447 * * * \\
\quad(11.99)\end{array}$ & $\begin{array}{l}0.5101 * * * \\
(25.11)\end{array}$ & $\begin{array}{l}0.5276 * * * \\
(25.82)\end{array}$ & $\begin{array}{c}0.4501 * * * \\
(29.18)\end{array}$ & $\begin{array}{c}0.7525 * * * \\
(-41.83)\end{array}$ & $\begin{array}{c}0.7573 * * * \\
(48.11)\end{array}$ \\
\hline Log Principal & $\begin{array}{c}-0.0374 * * * \\
(-2.76)\end{array}$ & $\begin{array}{l}-0.0229 \\
(-1.52)\end{array}$ & $\begin{array}{l}-0.0461 \\
(-1.56)\end{array}$ & $\begin{array}{c}-0.0410 * * * \\
(-3.04)\end{array}$ & $\begin{array}{c}-0.0340 * * \\
(-2.50)\end{array}$ & $\begin{array}{l}-0.0517 * * * \\
(-6.57)\end{array}$ & $\begin{array}{l}-0.0540 * * * \\
(-6.83)\end{array}$ & $\begin{array}{c}-0.0473 * * * \\
(-6.11)\end{array}$ \\
\hline $\begin{array}{l}\text { Long Term Debt Ratio x } \\
\text { Protection }\end{array}$ & $\begin{array}{l}0.1306 \\
(1.38)\end{array}$ & $\begin{array}{c}-0.4042^{*} \\
(-1.81)\end{array}$ & $\begin{array}{c}-0.6117 * * \\
(-2.44)\end{array}$ & $\begin{array}{l}0.1045 \\
(1.22)\end{array}$ & $\begin{array}{c}0.0483 \\
(0.57)\end{array}$ & $\begin{array}{c}-0.2540 * \\
(-1.79)\end{array}$ & $\begin{array}{c}-0.2898^{* *} \\
(-2.05)\end{array}$ & $\begin{array}{c}-0.3949 * * \\
(-2.46)\end{array}$ \\
\hline
\end{tabular}




\begin{tabular}{|c|c|c|c|c|c|c|c|c|}
\hline Log of Total Assets x Protection & $\begin{array}{c}-0.0230 * * * \\
(-2.75)\end{array}$ & $\begin{array}{c}-0.0602 * * \\
(-1.98)\end{array}$ & $\begin{array}{c}-0.0256 \\
(-1.52)\end{array}$ & $\begin{array}{c}-0.0180 * * \\
(-2.51)\end{array}$ & $\begin{array}{c}-0.0196^{* *} \\
(-2.61)\end{array}$ & $\begin{array}{c}-0.0106 \\
(-0.53)\end{array}$ & $\begin{array}{c}-0.0173 \\
(-0.85)\end{array}$ & $\begin{array}{c}-0.0515 * * \\
(-2.27)\end{array}$ \\
\hline Operating Income / Total Assets x & 0.4744 & $0.8279^{*}$ & 0.6997 & 0.1620 & -0.0836 & -0.2255 & -0.2465 & -0.1776 \\
\hline Protection & $(1.24)$ & $(1.75)$ & $(1.27)$ & $(0.46)$ & $(-0.34)$ & $(-0.79)$ & $(-0.86)$ & $(-0.56)$ \\
\hline Market-to-Book Ratio x Protection & $\begin{array}{c}-0.0396 * \\
(-1.87)\end{array}$ & $\begin{array}{c}-0.0061 \\
(0.95)\end{array}$ & $\begin{array}{c}0.0018 \\
(0.08)\end{array}$ & $\begin{array}{c}-0.0288 * * \\
(2.04)\end{array}$ & $\begin{array}{c}0.0254 * \\
(1.90)\end{array}$ & $\begin{array}{c}-0.0151^{*} \\
(-1.79)\end{array}$ & $\begin{array}{c}-0.0177 * * \\
(2.08)\end{array}$ & $\begin{array}{c}-0.0162 * * \\
(-2.39)\end{array}$ \\
\hline Family Presence x Stock Market & -1.0053 & -1.0024 & -0.0220 & -1.0049 & -1.0050 & -1.1107 & -0.0292 & $-2.1071 *$ \\
\hline Capitalization & $(-1.48)$ & $(-1.19)$ & $(-1.55)$ & $(-1.58)$ & $(-1.53)$ & $(-0.94)$ & $(-0.70)$ & $(-1.88)$ \\
\hline Intercept & $\begin{array}{c}-7.2017 \\
(-1.38)\end{array}$ & $\begin{array}{c}6.2737 * * * \\
\quad(4.45)\end{array}$ & $\begin{array}{c}9.7464 * * * \\
(3.57)\end{array}$ & $\begin{array}{c}2.2764 * * \\
(2.21)\end{array}$ & $\begin{array}{c}-5.7999 * \\
(1.72)\end{array}$ & $\begin{array}{c}6.3427 \\
(1.63)\end{array}$ & $\begin{array}{l}5.4318 \\
(1.39)\end{array}$ & $\begin{array}{c}6.2251 * * * \\
(4.06)\end{array}$ \\
\hline Firm Control Variables & YES & YES & YES & YES & YES & YES & YES & YES \\
\hline Time Dummies & YES & YES & YES & YES & YES & YES & YES & YES \\
\hline Industry Dummies & YES & YES & YES & YES & YES & YES & YES & YES \\
\hline Country Dummies & YES & YES & YES & YES & YES & YES & YES & YES \\
\hline Fixed Effects & $\begin{array}{l}\text { Country and } \\
\text { Industry }\end{array}$ & $\begin{array}{l}\text { Country and } \\
\text { Industry }\end{array}$ & $\begin{array}{l}\text { Country and } \\
\text { Industry }\end{array}$ & Country & Currency & $\begin{array}{l}\text { Country and } \\
\text { Industry }\end{array}$ & $\begin{array}{l}\text { Country and } \\
\text { Industry }\end{array}$ & Currency \\
\hline Number of Observations & 8,835 & 8,835 & 8,835 & 8,835 & 8,835 & 11,834 & 11,834 & 11,834 \\
\hline Adjusted $\mathrm{R}^{2}$ & 0.0536 & 0.1290 & 0.1474 & 0.0901 & 0.1095 & 0.3796 & 0.3720 & 0.3908 \\
\hline
\end{tabular}




\section{Table 7. Family Presence and Family Management}

This table provides the estimates of a linear regression model using various fixed effects for international bonds issues. The results reported in columns $1-6$ are obtained using Sample A consisting of 1,072 firms that issued 8,835 bonds over the period 1995-2000. The results shown in column 6 are for a sub-sample of bonds included in Sample A for which we are able to obtain information about bond ratings issued by credit rating agencies. The results in columns 7 and 8 are obtained using Sample B consisting of 328 U.S. and international firms with either a Level II or Level III ADR that issued 11,834 bonds over the period 1988-2002. The dependent variable is the yield spread of the bond issue defined as the offer yield-to-maturity minus the yield on the 3-month yield Treasury bond. We define the independent variables in Table 3. Standard errors are corrected for serial correlation and heteroscedasticity. The t-statistics appear in parentheses below parameter estimates. $* * *, * *$, and $*$ indicate significance at $1 \%, 5 \%$, and $10 \%$ level respectively.

\begin{tabular}{|c|c|c|c|c|c|c|c|c|}
\hline & 1 & 2 & 3 & 4 & 5 & 6 & 7 & 8 \\
\hline Family Presence (Dummy) & $\begin{array}{c}4.5957^{*} \\
(1.86)\end{array}$ & & $\begin{array}{c}1.8504^{*} \\
(1.91)\end{array}$ & & $\begin{array}{c}0.9024^{*} \\
(1.82)\end{array}$ & & $\begin{array}{c}4.2467 * * \\
(2.70)\end{array}$ & $\begin{array}{c}4.0958 * \\
(1.87)\end{array}$ \\
\hline Family Presence (\% Ownership) & & $\begin{array}{c}0.0705^{*} \\
(1.82)\end{array}$ & & $\begin{array}{c}0.0763 * \\
(1.81)\end{array}$ & & $\begin{array}{c}0.0184 * \\
(1.89)\end{array}$ & & \\
\hline Family Presence x Legality & $\begin{array}{c}-0.2221^{* *} \\
(-2.51)\end{array}$ & $\begin{array}{c}-0.0034^{*} \\
(-1.85)\end{array}$ & & $\begin{array}{c}-0.0037 * * \\
(-2.05)\end{array}$ & & & $\begin{array}{c}-0.2021 * \\
(-1.92)\end{array}$ & $\begin{array}{c}-0.2082 * * \\
(-2.28)\end{array}$ \\
\hline $\begin{array}{l}\text { Family Presence x } \\
\text { Creditors' Rights }\end{array}$ & & & $\begin{array}{c}-0.8824^{*} \\
(-1.91)\end{array}$ & & $\begin{array}{c}-0.5051 * \\
(-1.92)\end{array}$ & $\begin{array}{c}-0.0148 * \\
(-2.02)\end{array}$ & & \\
\hline Family Management & $\begin{array}{l}0.2589 * * \\
(2.69)\end{array}$ & $\begin{array}{c}0.2307^{*} \\
(1.80)\end{array}$ & $\begin{array}{c}0.2894 * \\
(1.89)\end{array}$ & $\begin{array}{l}0.2818^{* *} \\
(2.20)\end{array}$ & $\begin{array}{l}0.3262 * * \\
(2.08)\end{array}$ & $\begin{array}{l}0.5015 * * \\
(2.37)\end{array}$ & & $\begin{array}{l}0.2045^{* *} \\
(2.29)\end{array}$ \\
\hline Family Wedge & & & & & & & $\begin{array}{l}0.0157 \\
(0.98)\end{array}$ & $\begin{array}{c}0.0101 \\
(0.99)\end{array}$ \\
\hline Stock Market Capitalization & $\begin{array}{c}-5.0019 \\
(-1.34)\end{array}$ & $\begin{array}{c}-5.0227^{*} \\
(-1.68)\end{array}$ & $\begin{array}{c}-5.0054 \\
(-1.59)\end{array}$ & $\begin{array}{c}-5.0002 \\
(-1.04)\end{array}$ & $\begin{array}{c}-7.0245 * * \\
(-2.19)\end{array}$ & $\begin{array}{c}-7.0099 * \\
(-1.85)\end{array}$ & $\begin{array}{c}-5.0321 * \\
(-1.70)\end{array}$ & $\begin{array}{c}-5.0218^{*} \\
(-1.84)\end{array}$ \\
\hline Risk Free Rate & $\begin{array}{c}-0.1433 * * * \\
(-13.66)\end{array}$ & $\begin{array}{c}-0.1157 * * * \\
(-9.12)\end{array}$ & $\begin{array}{c}-0.1424 * * * \\
(-13.55)\end{array}$ & $\begin{array}{c}-0.2162 * * * \\
(-4.54)\end{array}$ & $\begin{array}{c}-0.2272 * * * \\
(-9.59)\end{array}$ & $\begin{array}{c}-0.3768 * * * \\
(-29.28)\end{array}$ & $\begin{array}{c}-0.1535 * * * \\
(-12.93)\end{array}$ & $\begin{array}{c}-0.1371 * * * \\
(-12.20)\end{array}$ \\
\hline Bond Rating & & & & & $\begin{array}{c}0.0661 * * * \\
(26.83)\end{array}$ & $\begin{array}{c}0.0648 * * * \\
(26.83)\end{array}$ & & \\
\hline Callable Bond Issue & & & & & $\begin{array}{c}0.2584 * * * \\
(7.89)\end{array}$ & $\begin{array}{l}0.2166^{* *} \\
(6.73)\end{array}$ & & \\
\hline Subordinated Bond Issue & & & & & $\begin{array}{c}0.3801 * * * \\
(5.74)\end{array}$ & $\begin{array}{c}0.3362 * * \\
(5.19)\end{array}$ & & \\
\hline Log Maturity & $\begin{array}{c}0.5021 * * * \\
(24.63)\end{array}$ & $\begin{array}{c}0.4692 * * * \\
(19.13)\end{array}$ & $\begin{array}{c}0.5003 * * * \\
(24.49)\end{array}$ & $\begin{array}{c}0.4942 * * * \\
(20.14)\end{array}$ & $\begin{array}{c}0.7553 * * * \\
(12.15)\end{array}$ & $\begin{array}{c}0.7651 * * * \\
(14.38)\end{array}$ & $\begin{array}{c}0.4911 * * * \\
(21.04)\end{array}$ & $\begin{array}{c}0.5014 * * * \\
(24.05)\end{array}$ \\
\hline Log Principal & $\begin{array}{c}-0.0338 * * \\
(-2.48)\end{array}$ & $\begin{array}{c}-0.0499 * * \\
(-2.87)\end{array}$ & $\begin{array}{c}-0.0369 * * * \\
(-2.70)\end{array}$ & $\begin{array}{c}-0.0400 * * \\
(-2.29)\end{array}$ & $\begin{array}{c}-0.0568 * * * \\
(-7.24)\end{array}$ & $\begin{array}{c}-0.0513 * * * \\
(-6.70)\end{array}$ & $\begin{array}{c}-0.0340 * * \\
(-2.67)\end{array}$ & $\begin{array}{c}-0.0342 * * \\
(-2.51)\end{array}$ \\
\hline
\end{tabular}




\begin{tabular}{|c|c|c|c|c|c|c|c|c|}
\hline Long Term Debt Ratio & $\begin{array}{c}0.4795 * * * * \\
(3.70)\end{array}$ & $\begin{array}{c}0.4182 * * \\
(2.36)\end{array}$ & $\begin{array}{c}0.4900 * * * \\
(3.77)\end{array}$ & $\begin{array}{c}0.8226^{* * *} \\
(4.73)\end{array}$ & $\begin{array}{c}0.2865^{* *} \\
(2.57)\end{array}$ & $\begin{array}{c}0.4094 * * * \\
(3.67)\end{array}$ & $\begin{array}{c}0.4722 * * * * \\
(3.76)\end{array}$ & $\begin{array}{c}0.4918 * * * * \\
(3.75)\end{array}$ \\
\hline Log of Total Assets & $\begin{array}{c}-0.0348 * * * \\
(-3.35)\end{array}$ & $\begin{array}{c}-0.0726 * * * \\
(-4.55)\end{array}$ & $\begin{array}{c}-0.0290 * * * \\
(-2.80)\end{array}$ & $\begin{array}{c}-0.0688 * * * \\
(-4.44)\end{array}$ & $\begin{array}{c}-0.0252 * * \\
(-2.00)\end{array}$ & $\begin{array}{c}-0.0504 * * * \\
(-3.68)\end{array}$ & $\begin{array}{c}-0.0351 * * * \\
(-3.42)\end{array}$ & $\begin{array}{c}-0.0359 * * * \\
(-3.49)\end{array}$ \\
\hline Operating Income / Total Assets & $\begin{array}{c}-2.2360 * * * \\
(-7.01)\end{array}$ & $\begin{array}{c}-2.0940 * * * \\
(-5.35)\end{array}$ & $\begin{array}{c}-2.3595 * * * \\
(-7.39)\end{array}$ & $\begin{array}{c}-2.2854 * * * \\
(-6.06)\end{array}$ & $\begin{array}{c}-0.1201 \\
(-1.49)\end{array}$ & $\begin{array}{c}-0.1154 \\
(-1.46)\end{array}$ & $\begin{array}{c}-2.011 * * * \\
(-6.81)\end{array}$ & $\begin{array}{c}-2.1819 * * * \\
(-6.86)\end{array}$ \\
\hline Market-to-Book Ratio & $\begin{array}{c}0.0008 \\
(0.96)\end{array}$ & $\begin{array}{c}0.0008 \\
(0.79)\end{array}$ & $\begin{array}{c}0.0008 \\
(0.91)\end{array}$ & $\begin{array}{c}0.0010 \\
(0.98)\end{array}$ & $\begin{array}{c}0.0141 \\
(1.20)\end{array}$ & $\begin{array}{c}0.0210 \\
(1.45)\end{array}$ & $\begin{array}{c}0.0009 \\
(0.95)\end{array}$ & $\begin{array}{c}0.0008 \\
(0.95)\end{array}$ \\
\hline Intercept & $\begin{array}{c}4.8065 \\
(1.30)\end{array}$ & $\begin{array}{c}7.9141 * * \\
(2.00)\end{array}$ & $\begin{array}{c}6.6930^{*} \\
(1.81)\end{array}$ & $\begin{array}{c}3.3960 \\
(1.57)\end{array}$ & $\begin{array}{c}9.5276^{*} \\
(1.64)\end{array}$ & $\begin{array}{c}7.6090 * * * \\
(2.83)\end{array}$ & $\begin{array}{c}4.6152 \\
(1.28)\end{array}$ & $\begin{array}{c}4.5278 \\
(1.39)\end{array}$ \\
\hline Time Dummies & YES & YES & YES & YES & YES & YES & YES & YES \\
\hline Industry Dummies & YES & YES & NO & YES & YES & YES & YES & YES \\
\hline Country Dummies & YES & YES & YES & YES & YES & YES & YES & YES \\
\hline Fixed Effects & $\begin{array}{l}\text { Country and } \\
\text { Industry }\end{array}$ & $\begin{array}{l}\text { Country and } \\
\text { Industry }\end{array}$ & Industry & Currency & $\begin{array}{l}\text { Country and } \\
\text { Industry }\end{array}$ & Currency & $\begin{array}{l}\text { Country and } \\
\text { Industry }\end{array}$ & $\begin{array}{l}\text { Country and } \\
\text { Industry }\end{array}$ \\
\hline Number of Observations & 8,835 & 8,835 & 8,835 & 8,835 & 11,834 & 11,834 & 8,835 & 8,835 \\
\hline Adjusted $\mathrm{R}^{2}$ & 0.0792 & 0.0728 & 0.0884 & 0.1689 & 0.4247 & 0.4788 & 0.0801 & 0.0805 \\
\hline
\end{tabular}


Table 8. The Effect of Non-Family Blockholders

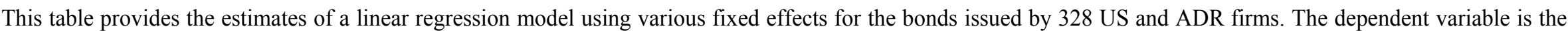

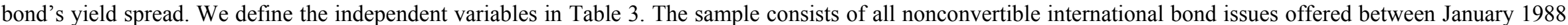

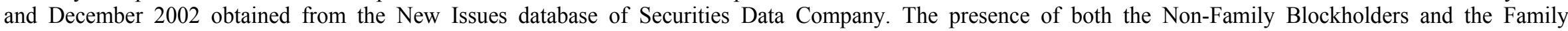

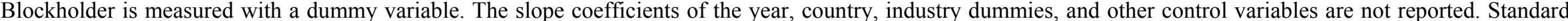

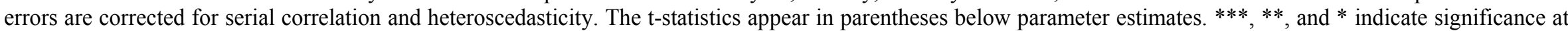
$1 \%, 5 \%$, and $10 \%$ level respectively.

\begin{tabular}{|c|c|c|c|c|c|c|c|c|}
\hline & 1 & 2 & 3 & 4 & 5 & 6 & 7 & 8 \\
\hline Non-Family Blockholder & $\begin{array}{l}0.3152 \\
(1.06)\end{array}$ & & & $\begin{array}{c}0.2218 \\
(0.95)\end{array}$ & & & & \\
\hline Blockholder & -0.0978 & & & -0.0715 & & & & \\
\hline Creditors' Rights & $(-0.95)$ & & & $(-0.71)$ & & & & \\
\hline Non-Family Inside Blockholder & & $\begin{array}{c}-0.0519 \\
(-1.12)\end{array}$ & & & $\begin{array}{c}-0.0422 \\
(-0.94)\end{array}$ & & & \\
\hline $\begin{array}{l}\text { Non-Family Inside Blkr. } \\
\text { Creditors' Rights }\end{array}$ & $\mathrm{x}$ & $\begin{array}{c}0.0105 \\
(0.98)\end{array}$ & & & $\begin{array}{c}0.0097 \\
(0.85)\end{array}$ & & & \\
\hline Non-Family Outside Blockholder & & & $\begin{array}{c}0.3902 \\
(1.07)\end{array}$ & & & $\begin{array}{c}0.2811 \\
(0.98)\end{array}$ & & \\
\hline $\begin{array}{l}\text { Non-Family Outside Blkr. } \\
\text { Creditors' Rights }\end{array}$ & $\mathrm{x}$ & & $\begin{array}{l}-0.1084 \\
(-1.04)\end{array}$ & & & $\begin{array}{l}-0.0802 \\
(-0.87)\end{array}$ & & \\
\hline Family Presence & & & & & & & $\begin{array}{l}1.2964 * * \\
(2.08)\end{array}$ & $\begin{array}{l}1.081 * \\
(1.870)\end{array}$ \\
\hline Family Presence x Creditors' & & & & & & & $-0.6594 * *$ & $-0.4902 *$ \\
\hline Rights & & & & & & & $(-2.14)$ & $(-1.92)$ \\
\hline Family Presence Together with & & & & & & & -0.1471 & -0.1105 \\
\hline Non-Family Blockholder & & & & & & & $(-1.43)$ & $(-1.02)$ \\
\hline Control Variables & YES & YES & YES & YES & YES & YES & YES & YES \\
\hline Time Dummies & YES & YES & YES & YES & YES & YES & YES & YES \\
\hline Industry Dummies & YES & YES & YES & YES & YES & YES & YES & YES \\
\hline Country Dummies & YES & YES & YES & YES & YES & YES & YES & YES \\
\hline Fixed Effects & $\begin{array}{l}\text { Country and } \\
\text { Industry }\end{array}$ & $\begin{array}{l}\text { Country and } \\
\text { Industry }\end{array}$ & $\begin{array}{l}\text { Country and } \\
\text { Industry }\end{array}$ & Firm & Firm & Firm & $\begin{array}{l}\text { Country and } \\
\text { Industry }\end{array}$ & Firm \\
\hline Number of Observations & 11,834 & 11,834 & 11,834 & 11,834 & 11,834 & 11,834 & 11,834 & 11,834 \\
\hline Adjusted $\mathrm{R}^{2}$ & 0.3712 & 0.3802 & 0.3795 & 0.1508 & 0.1529 & 0.1498 & 0.3948 & 0.1611 \\
\hline
\end{tabular}

